NBER WORKING PAPER SERIES

\title{
WHY WORLD REDISTRIBUTION FAILS
}

\author{
Wojciech Kopczuk \\ Joel Slemrod \\ Shlomo Yitzhaki \\ Working Paper 9186 \\ http://www.nber.org/papers/w9186 \\ NATIONAL BUREAU OF ECONOMIC RESEARCH \\ 1050 Massachusetts Avenue \\ Cambridge, MA 02138 \\ September 2002
}

The views expressed herein are those of the authors and not necessarily those of the National Bureau of Economic Research.

(C) 2002 by Wojciech Kopczuk, Joel Slemrod, and Shlomo Yitzhaki. All rights reserved. Short sections of text, not to exceed two paragraphs, may be quoted without explicit permission provided that full credit, including $(\mathrm{C}$ notice, is given to the source. 
Why World Redistribution Fails

Wojciech Kopczuk, Joel Slemrod, and Shlomo Yitzhaki

NBER Working Paper No. 9186

September 2002

JEL No. F35, H21, H23

\begin{abstract}
An optimal linear world income tax that maximizes a border-neutral social welfare function provides a drastic reduction in world consumption inequality, dropping the Gini coefficient from 0.69 to 0.25 . In contrast, an optimal decentralized (i.e., within countries) redistribution has a miniscule effect on world income inequality. Thus, the traditional public finance concern about the excess burden of redistribution cannot explain why there is so little world redistribution.

Actual foreign aid is vastly lower than the transfers under the simulated world income tax, suggesting that countries such as the United States either place a much lower value on the welfare of foreigners or else expect that a very significant fraction of cross-border transfers is wasted. The product of the welfare weight and one minus the share of transfers that are wasted constitutes an implied weight that the United States assigns to foreigners. We calculate that value to be as low as $1 / 2000$ of the value put on the welfare of an American, suggesting that U.S. policy implicitly assumes either that essentially all transfers are wasted or places essentially no value on the welfare of the citizens of the poorest countries.
\end{abstract}

Joel Slemrod

University of Michigan

A2120D Business School

Ann Arbor, MI 48109

and NBER

jslemrod@umich.edu

Shlomo Yitzhaki

Central Bureau of Statistics, Israel

shlomo.yitzhaki@huji.ac.il
Wojciech Kopczuk

Department of Economics

University of British Columbia

Kopczuk@interchange.ubc.ca 


\section{Introduction}

In May, 2002 rock star Bono and U.S. Secretary of the Treasury Paul O’Neill toured Africa together. At each stop they publicly aired their different views on the need and effectiveness of foreign aid. Bono insisted that more aid is needed to lift Africa out of desperate poverty, implying that that it is largely the mendacity of developed countries that prevents more aid. Secretary O’Neill argued that much aid has done little to reduce poverty, owing in large part to waste and corruption.

This high-profile tour generated wide media coverage of global poverty and global income inequality. But the same debate has been ongoing for many years. Gross disparities of income across countries ${ }^{1}$ have drawn attention to the small amount of resources transferred from the rich countries of the world to the poor countries, and have given rise to calls that the rich countries devote much more of their resources to foreign aid. For example, Sachs (2001) has called for the United States to double its aid budget and devote the funds to disease control, primary education, clean water, and other vital needs of impoverished places.

The unwillingness of the United States and other developed countries to substantially raise their foreign aid may reflect one or both of two factors: the citizens of rich countries place a very low value on the welfare of the citizens of poor countries, or they may shy away from transfers because of the large efficiency cost that would plague such efforts. This cost may have two sources. One is the concern expressed by Secretary O'Neill and others that the funds would be not reach the targeted groups due to waste and 
corruption. Another type of cost relates to the traditional concern of public finance economists that the process of taxing the well off and transferring the proceeds to the less well off causes disincentives. The economic cost of these disincentives limits the optimal amount of cross-country transfers that would be undertaken even by a policymaker with egalitarian impulses to redistribute from the globally rich to the globally poor.

From this public finance perspective, it is clear that the problem of global redistribution has the same structure as the problem each country faces-trading off the efficiency costs of a progressive tax system against the more equal distribution of welfare it achieves. In fact, most countries achieve some degree of redistribution through their own tax-and-transfer system. Clearly, the extent of overall, world, redistribution is small relative to world inequality because cross-country transfers are minimal. The question of whether these minimal transfers are at least approximately optimal and what the optimal transfers would be requires further investigation, however.

In this paper we explore this question quantitatively as follows. We first calculate each country's optimal redistributive policy, assuming that each country sets its tax system to maximize a concave social welfare function of individual utility levels, knowing that the tax system will influence individuals' choices. Then each country will set its own tax schedule that is more or less progressive based on the distribution of incomes (more precisely, the ability to earn income) within that country. Even though the social welfare function is concave, the desire to redistribute is constrained by the economic cost of the marginal tax rates the redistribution requires. Using data on income differences.

${ }^{1}$ Milanovic (2002) has shown that the major source of world income inequality is cross-country 
inequality and assumptions about utility functions that imply how responsive behavior is to taxation, we calculate the optimal income tax system in each of 118 countries and characterize the amount of redistribution that these decentralized systems produce.

Now we consider the hypothetical case of a world income tax, where the same tax schedule applies to everyone regardless of where they live, and which therefore allows for transfers across countries. We first consider the case where there is no waste (other than excess burden) from cross-country transfers and that the tax setter is border-neutral, meaning that each person's welfare enters the social welfare function the same regardless of where he or she lives. Assuming further that the world decision maker has the same preferences as each country about the tradeoff between the mean and distribution of incomes (i.e., an equally concave social welfare function), and faces the same costs from imposing redistribution, we can solve for the optimal progressivity of the world income tax. The solution depends on the inequality of world incomes, and not on the degree of inequality within countries.

The results of simulating these stylized models reveal that the decentralized taxand-transfer scheme makes hardly any dent in the world income inequality. This is so even though countries pick progressive tax systems on their own. In contrast, an optimal world income tax would significantly reduce the world inequality of consumption, albeit with a larger efficiency cost and at the cost of a reduction in welfare of citizens of the richest 25 countries. Thus, we conclude that a concern about the excess burden of crosscountry transfers cannot explain why foreign aid is so low--what limits these transfers is not the efficiency cost of the redistribution. 
What might? One possibility is that weights put on the welfare of foreigners are lower than those put on the welfare of citizens, as implied by Bono. Another is that transfers are not used efficiently, as implied by Secretary O’Neill. In the final section we address these possibilities by allowing the policy makers in the rich countries to place a lower value on the welfare of the citizens of other countries at any given level of income compared to their own citizens, and/or expect that a fraction of cross-country transfers would be wasted. With our parameter assumptions we cannot distinguish between the Bono and O'Neill scenarios, but we can calculate precisely how low the product of that relative value and the share of transfers that are wasted must be in order to generate the current level of cross-country transfers, in the form of foreign aid, given by rich to poor countries.

It is shockingly low. In our baseline case, foreigners are on average valued by the U.S. at just $16 \%$ of an average American, with the citizens of the poorest countries weighted by as little as $1 / 20^{\text {th }}$ of one percent. The latter value implies either that U.S. puts essentially no weight on the welfare of those individuals or that $1 / 2000^{\text {th }}$ of the transfer is wasted or a combination of both.

\section{Methodology}

\subsection{Calculating the Optimal Linear Income Tax}

Our central analytical tool is a model of the optimal income tax structure, as pioneered by Mirrlees (1971). The idea is that the government chooses an income tax function that maximizes a given social welfare function, subject to an exogenously specified revenue requirement and the constraint that individuals will choose the levels of 
consumption and leisure that maximize their utility subject to their own budget constraints, which depend on the tax system chosen.

There are three key elements of the problem. The first is the degree of concavity of the social welfare function, which captures how society makes the tradeoff between the sum of utilities and the distribution of utilities. Second is the elasticity of substitution between leisure and consumption in individuals' utility functions (which are assumed to be identical); this determines the amount of distortion, or welfare cost, for any given tax structure. The final element is the distribution of abilities, where an individual's ability is presumed to be equal to the pre-tax wage rate. Loosely speaking, the optimal income tax structure trades off the social welfare gains of a more equal distribution of utilities against the efficiency cost caused by the structure of marginal tax rates needed to achieve any given amount of redistribution.

Although the optimal income tax literature has explored the sensitivity of the results to various assumptions about the social welfare function, the distribution of abilities, and the magnitude of behavioral response, it has not been used to quantitatively explore the implications of a decentralized system of redistribution in a world of gross inequalities across countries. This is the task we begin below.

\subsection{Choosing the Model Parameters}

There are two scenarios that we wish to compare. One is a decentralized solution, in which each country selects its own optimal linear income tax system. The other one is a world income tax system, in which the decision maker designs a single linear income tax that applies to all individuals in the world. This exercise requires making a host of assumptions about the distribution of earning potential, the utility function, welfare 
function, behavioral elasticities and stylized economies we study. In what follows we review the main issues.

\subsubsection{The Distribution of Abilities}

The dispersion of abilities is critical because, in general and ceteris paribus, the optimal linear income tax will be more progressive (i.e., feature a higher demogrant and higher tax rate) the more unequal is the initial distribution of earning potential within the jurisdiction. Mirrlees (1971) presents an example in which widening the distribution of skills, assumed equal to wage rates, increased the optimal marginal tax rates; he concludes that the dispersion of skills necessary to imply marginal tax rates much higher than the 20 to 40 percent range is unrealistically high. In his baseline numerical simulation, he sets the value of the standard deviation of the associated normal distribution (denoted $\sigma$ ) in the assumed logarithmic distribution of skills to be equal to 0.39, derived from Lydall's (1968) figures for the distribution of income from employment in various countries. When Mirrlees repeated the simulation with $\sigma=1.0$, a much wider dispersion of ability, he reported that the optimal tax schedule

"is in almost all respects very different. Tax rates are very high: a large proportion of the population is allowed to abstain from productive labour. The results seem to say that, in an economy with more intrinsic inequality in economic skill, the income tax is a more important weapon of public control than it is in an economy where the dispersion of innate skills is less. The reason is, presumably, that the labour-discouraging effects of the tax are more important, relative to the redistributive benefits, in the latter case." 
Stern (1976), examining only flat-rate tax systems, corroborates Mirrlees finding. For his base case featuring an elasticity of substitution between goods and leisure of 0.4 , when $\sigma=0.39$, the optimal marginal tax rate is 0.225 , but it rises to 0.623 when $\sigma=1$. Cooter and Helpman (1974) perform a variety of numerical simulations, and find that for all of them the optimal marginal tax rate increased as the constant-mean ability distribution spreads out. ${ }^{2}$

Of course, innate ability is unobservable, so its dispersion is not knowable, either. What is available, and are collected in Deininger and Squire (1996), are estimates of Gini coefficients for 138 countries. These estimates were produced from a variety of micro data sources, and come from studies of varying quality. They identify Gini coefficients based on actual observation of individual units drawn from household surveys, based on comprehensive coverage of the population, and based on comprehensive coverage of different income sources as well as of population groups. World Bank (2000, Table 2.8) is a more recent source of Gini coefficients. These estimates are based on survey data obtained from government statistical agencies and World Bank country departments, and in many cases overlap with the Deininger and Squire (1996) observations. In our simulations, we use the World Bank (2000) estimates as the primary source, and resort to the "high-quality" observations in Deininger and Squire (1996) for countries that are not present in that dataset.

${ }^{2}$ Helpman and Sadka (1978) claim that this result is not general, but offer only a trivial counterexample that features a Rawlsian (maximin) social welfare function and a fixed lowest ability level of zero. They argue that there should exist counter-examples with more general social welfare functions, but admit they were unable to identify any such example. 
A more vexing problem is that the studies sometimes calculate the inequality of pre-tax income, sometimes calculate the inequality of after-tax income, and sometimes calculate the inequality of consumption. Of course, none calculates the inequality of ability. By making strong assumptions about the process that generates income, one could claim to have recovered the distribution of abilities that is consistent with the data. For example, for a given and common utility function and tax system, one could convert the distribution of labor earnings into the distribution of abilities. This is the procedure we follow.

Because of the greater variability of annual income compared to annual consumption, measures of inequality based on the former will tend to be higher. Deininger and Squire report that in their sample the mean difference between the expenditure-based Gini coefficients and those based on gross income is 6.6. They also report that for the nineteen pairs of Gini coefficients computed using the Luxembourg Income study data, those based on after-tax income were on average 3 points lower than those based on gross income; this sample includes, however, only one developing country (Mexico). Clearly, the quantitative importance of this effect will depend on the effective progressivity of the tax system in place.

In what follows we assume that the distribution of abilities in each country is lognormal. Then, we parameterize the distribution so that the resulting Gini coefficient of income or consumption for a given country under a certain baseline income tax system ${ }^{3}$ is equal to the empirical value. In this exercise, gross income is assumed to equal labor

\footnotetext{
${ }^{3}$ The baseline income tax system features a marginal tax rate of 0.30 .
} 
income of the individual, and both consumption and net income are assumed to correspond to after-tax income.

\subsubsection{The Individual Utility Function}

The individual utility function is a critical element of the problem because it determines the substitutability between leisure and consumption, which in turn reveals the marginal efficiency cost of any degree of tax progressivity. In his simulation analyses of the optimal linear income tax, Stern (1976) focuses on a constant-elasticity-ofsubstitution (henceforth CES) utility function with an elasticity of substitution of 0.4 , based on his reading of the labor supply elasticity literature available at that time. Depending on how it is read, the literature since then suggests considering both a lower and a higher number: lower because the aggregate elasticity of substitution between leisure and consumption may be less than $0.4,{ }^{4}$ higher because labor supply is only one dimension of behavioral response to taxation that involves an efficiency cost, and research on the elasticity of taxable income suggests that an elasticity of 0.6 may be appropriate (Auten and Carroll 1999; Gruber and Saez 2000; Slemrod, 1998). Although in this case the relevant behavioral response is summarized by an elasticity of taxable income rather than an elasticity of substitution between consumption and leisure, in order to be comparable with most of the optimal income tax literature we retain the standard modeling. However, we assign higher behavioral responses than have been found for labor supply, in order to represent the whole range of possible responses.

Somewhat surprisingly, the "income elasticity" of optimal progressivity - do richer countries choose more progressive tax systems? - in this class of models has been 
almost completely ignored. Indeed, the answer is not obvious. A proportional increase in all individuals' abilities changes the set of tax systems that raise the required amount of revenue. Under certain conditions, the admissible tax systems are simply scaled up in the sense that an equi-proportionate change in all abilities, revenue, and the demogrant, holding the marginal tax rate constant, is still admissible (but perhaps no longer is optimal). However, holding taxes and the degree of inequality constant, the commonly used CES utility functions with an elasticity of substitution below unity imply that in countries with high average ability levels there is much less labor supply, relative to countries with low average abilities, than is apparently observed. As a result, the tax base and revenue collected increase less than proportionally, so that it is not possible to sustain a scaled up tax system.

One approach to these issues is to consider the class of utility functions that yield the "scale" elasticity of zero. ${ }^{5}$ As discussed by King, Plosser, and Rebelo (1982), this class has the form $\mathrm{U}(\ln (C)+\mathrm{g}(L))$, where $C$ is consumption and $L$ is leisure. The motivation for examining this utility function is to ensure that simulations yield results that are not grossly inconsistent with the empirical observation that labor supply is broadly similar across countries with widely varying average income levels. Note, though, that the optimal tax system may not simply scale up, because the optimum also depends on the social welfare function. What the assumption about utility functions guarantees is that, ceteris paribus, the income elasticity of the optimal tax structure depends only on the social welfare function.

\footnotetext{
${ }^{4}$ For a survey of the labor supply literature see Blundell and MaCurdy (1999).
} 
In what follows, we present results for the Cobb-Douglas utility function. This is the only CES utility function that is also in the King-Plosser-Rebelo class. This choice implies a compensated elasticity of labor supply of one, which is high in the context of the literature on the elasticity of taxable income, but within the range of available estimates.

\subsubsection{The Social Welfare Function}

Although there have been attempts to recover a society's social welfare function (henceforth SWF) from examining actual government policies, or by examining individual risk aversion, for the most part economists have not tried to defend a particular SWF. Instead, they have investigated the implications of alternative specifications of the SWF for the solution to the problem at hand. We adopt that strategy as well.

To be consistent with the earlier literature, we investigate SWFs of the type introduced by Atkinson (1970), that are of the form $\mathrm{W}=\Sigma(1-\mathrm{v})^{-1} \mathrm{U}^{1-\mathrm{v}}$. The higher the value of $\mathrm{v}$, the larger is the concavity of the SWF, and the larger is the implied willingness of the society to trade off the sum of utilities for a more equal distribution of the utilities. We investigate the implications of three values of $\mathrm{v}: 0.5,2.0$, and 5.0, but concentrate on the case of $v=2.0$, which is Stern's (1976) central case, as well. Whatever value we choose, we assume it is the same for all countries and for the designer of the world income tax. In so doing, we skirt the fascinating but difficult question of whether the degree of egalitarianism differs across countries, including whether it differs systematically depending on the mean level of income or on the distribution of abilities.

\footnotetext{
${ }^{5}$ Write leisure as $L(s w, s G)$ i.e., a function of wage rate and income, where $\mathrm{s}$ is a scalar. The necessary property for a zero scale elasticity is $d L / d s=0$. Note that this property depends on a combination
} 


\subsection{Introducing Tradables and PPP Differences}

In practice, there are significant differences in countries' real price levels. Ignoring these differences would have some peculiar implications when we allow for transfers across countries. The centralized budget constraint would simply add up nominal taxes and subsidies of different economies, so that it would amount to assuming that U.S. and Indian consumption can be exchanged one for one. While this may be correct for tradable commodities, it is not correct for the non-tradable ones. There are also implications for the location of production. Ignoring the presence of non-tradable commodities and holding price levels fixed while allowing for large international transfers will invariably lead to poor countries shutting down their production and relying solely on transfers. The prediction of $100 \%$ voluntary unemployment across the Third World would be a highly undesirable model feature.

In this section we enrich the model so as to address these issues in a more satisfactory way. The model features two sectors in each country that produce tradable and non-tradable commodities, denoted $\mathrm{T}$ and $\mathrm{N}$, respectively. We normalize the (world) price of tradable goods to one. Non-tradable commodities are produced and consumed domestically. Because people want to consume both types of goods, some non-tradable goods have to be produced in each country. Equilibrium is reached by the adjustment of relative wages in the two sectors. ${ }^{6}$ The details of the model follow.

of income and price responses.

${ }^{6}$ An alternative equilibrating mechanism would allow the substitution of labor for capital. We do not, however, consider this to be a realistic possibility. For example, we are not aware of a conceivable way of substituting capital for the time of a barber. This example captures an important feature of at least some non-tradable commodities: they require the time of an individual. In other words, highly-skilled individuals are not more productive (or at least they are not much more productive) than the low-skilled ones. 


\subsubsection{Individuals}

Assume that there is a continuum of individuals characterized by (heterogeneous) skill levels $a$. We consider the following utility function $u(T, N, L)=\left[(1-\alpha)\left(T^{\delta} N^{1-\delta}\right)^{-r}+\alpha L^{-r}\right]^{-1 / r}$. This utility function is CES between leisure and consumption commodities. The Cobb-Douglas consumption segment implies that the fraction $\delta$ of total income is spent on tradables, while the rest is spent on non-tradables. Denoting the price of non-tradables in country $i$ as $p_{i}$, consumption of the two types of goods is therefore given by

$$
T^{D}=\delta(G+(1-t) w(a)(1-L)), \quad N^{D}=\frac{1-\delta}{p_{i}}(G+(1-t) w(a)(1-L)),
$$

where $w(a)$ is the wage rate of an individual with the skill level of $a$.

\subsubsection{Production}

We assume that production in both sectors takes place using only labor. However, the relative productivity of workers with different skill levels varies by sector. Each individual works in just one sector. More specifically, we assume that production in the tradable sector takes place using efficiency units of labor, such that

$$
T^{s}=\int_{S_{T}} a(1-L(a)) d F(a),
$$

where the integration takes place over the set of workers who choose to work in the tradable sector, $S_{T}$. The productivity of a worker in the non-tradable sector is assumed to be more closely related to the amount of time that is invested in the activity, although it is positively correlated with skill. In particular, we assume that the productivity in the nontradable sector is $a^{d}$, where $0 \leq d<1$, so that 


$$
N^{s}=\int_{S_{N}} a^{d}(1-L(a)) d F(a)
$$

where $S_{N}$ is the set of workers that choose to work in the non-tradable sector. In the extreme case when $d=0$, each individual is equally productive in the non-tradable sector. In general, more skilled individuals are more productive in the non-tradable sector, but by a smaller (and decreasing) factor than in the tradable sector. There are no country-specific productivity differentials other than differences in the skill levels of individuals.

\subsubsection{Equilibrium}

We assume that both sectors are competitive. Because the tradable good is the numeraire, the individual who chooses to work in the tradable sector will receive a wage rate equal to $a$ per unit of his time. The individual who chooses to work in the nontradable sector is paid $p_{i} a^{d}$. Thus,

$$
w(a)= \begin{cases}a, & a>p_{i} a^{d}, \\ p_{i} a^{d}, & \text { otherwise }\end{cases}
$$

Because it is assumed that $d<1$, low-skilled workers will choose to work in the nontradable sector and high-skilled workers will choose to work in the tradable sector, although the cutoff level of skill will differ from country to country and depend on the tax system in place.

\subsubsection{Features of the equilibrium}

The price of the non-tradable commodity determines the potential wages of every individual in each of the two sectors, which determines the sector in which individual is working and allows us to solve for individual consumption and labor decisions. Therefore, the price of non-tradables in a given country is sufficient to determine the 
aggregate demand and supply of non-tradables. In the equilibrium, the price adjusts to make them equal. ${ }^{7}$ Total imports of tradables must be equal to the transfer to the country:

$$
T^{D}-T^{S}=\text { transfer },
$$

because transfers can only take the form of tradables.

One feature of equilibrium is that richer economies have a higher price of nontradable commodities, so that the overall price level in richer economies is higher. This is also a well-known property of actual relative price levels, remarked upon by Balassa (1964) and Samuelson (1964), ${ }^{8}$ who suggest explanations that are in the same spirit as this model.

\subsection{Calibration Methodology and Baseline Results}

Table A-1 lists the key data all of the 118 countries we examine. The first column lists the population in 1999. Note that, although not all countries are considered in the simulations, the countries that are considered comprise about $93 \%$ of world population. Next, the table shows the mean per capita income, in PPP dollars, followed by the PPP deflator. The level of gross national product (GNP) per capita varies from a low of $\$ 414$ (for Sierra Leone) to $\$ 38,247$ (for Luxembourg). The next two columns present the Gini coefficients taken from World Bank (2000) or Deininger and Squire (1996), and the year for which the coefficient was calculated. There is significant variation in these coefficients, ranging as low as 0.19 for the Slovak Republic and exceeding 0.60 for Brazil, the Central African Republic, Gabon, Malawi and Sierra Leone. Although recall

\footnotetext{
${ }^{7}$ The level of inequality may affect the price level because it affects the relative supply of low and high skilled labor. Note also that $100 \%$ unemployment will not occur, because in this case no non-tradable goods would be produced.

${ }^{8}$ See Rogoff (1996) for a recent survey.
} 
that the Gini coefficients are not directly comparable, the wide range strongly suggests that inequality varies greatly across countries.

We assume that the utility function is Cobb-Douglas $(r=0)$. This leaves three world-wide parameters to be selected: $\delta$, the share of tradables in consumption; $d$, the productivity parameter in the non-tradable sector; and $\alpha$, the share of leisure. There are also two country-specific parameters: the extent of inequality and the average skill (a) level (the distribution of $a$ is assumed to be log-normal). Finally, the calibration procedure requires that each country's revenue constraint is satisfied under the baseline tax system, adding the third country-specific requirement and pinning down the demogrant under the baseline tax system.

In calibrating the model, we seek to match actual data regarding economy-specific mean incomes, Gini coefficients, and PPP indices, plus an overall world-wide average labor supply of 0.25 . We first assume a standardized tax system with $t=0.3$ in all countries. Then, given $d, \delta$ and $\alpha$, we adjust the distribution of skills in each country to exactly match the empirical mean income and relevant Gini coefficient. This requires solving for an equilibrium at each step, and yields the price of non-tradables and consumption of the two types of commodities. Having this information for all countries makes it possible to compute the PPP indices. ${ }^{9}$

The next step is to select the values of $d, \delta$, and $\alpha$ that generate average labor supply at the desired level and that minimize the sum of squared deviations of the

${ }^{9}$ We use the Eltetö-Köves-Szulc (EKS) method that was used to compute PPP in our data. See Hill (1997) for a discussion of purchasing power parity methods and the EKS formula (equation 50). 
Table 1: Summary statistics about the baseline calibrated world economy, selected countries.

\begin{tabular}{|c|c|c|c|c|c|c|c|c|c|}
\hline & \multirow{2}{*}{$\begin{array}{c}\text { Mean full } \\
\text { time income }\end{array}$} & \multirow{2}{*}{$\begin{array}{l}\text { Mean Labor } \\
\text { supply }\end{array}$} & \multirow{2}{*}{$\begin{array}{c}\text { Mean } \\
\text { Consumption }\end{array}$} & \multirow{2}{*}{$\begin{array}{c}\text { Unemploy } \\
\text { ment }\end{array}$} & \multirow{2}{*}{$\begin{array}{c}\text { Labor } \\
\text { income } \\
\text { Gini }\end{array}$} & \multirow{2}{*}{$\begin{array}{c}\text { Consumpt } \\
\text { ion Gini }\end{array}$} & \multicolumn{3}{|c|}{ Consumption Percentiles } \\
\hline & & & & & & & $5 \%$ & $50 \%$ & $95 \%$ \\
\hline World & 15,849 & 0.25 & 5,060 & $0 \%$ & 0.72 & 0.68 & 609 & 1,814 & 27,860 \\
\hline United States & 95,093 & 0.27 & 30,636 & $0 \%$ & 0.41 & 0.29 & 17,692 & 21,206 & 70,711 \\
\hline Israel & 55,230 & 0.27 & 17,458 & $0 \%$ & 0.36 & 0.25 & 10,817 & 13,372 & 36,518 \\
\hline Poland & 12,639 & 0.28 & 3,963 & $0 \%$ & 0.33 & 0.23 & 2,538 & 3,157 & 7,896 \\
\hline Peru & 7,278 & 0.26 & 2,391 & $0 \%$ & 0.46 & 0.32 & 1,298 & 1,508 & 5,982 \\
\hline El Salvador & 5,635 & 0.25 & 1,898 & $0 \%$ & 0.52 & 0.36 & 960 & 1,142 & 5,077 \\
\hline Papua New Guinea & 2,084 & 0.20 & 801 & $0 \%$ & 0.73 & 0.51 & 304 & 410 & 2,143 \\
\hline India & 1,319 & 0.25 & 449 & $0 \%$ & 0.54 & 0.38 & 221 & 266 & 1,230 \\
\hline Kyrgyz Republic & 934 & 0.27 & 300 & $0 \%$ & 0.41 & 0.28 & 175 & 210 & 680 \\
\hline Ethiopia & 289 & 0.24 & 100 & $0 \%$ & 0.57 & 0.40 & 47 & 58 & 285 \\
\hline
\end{tabular}

simulated PPP levels of 118 countries from their actual 1999 PPP price levels. ${ }^{10}$ This

procedure generates calibrated parameter values of $\delta=.79, d=.12, \alpha=.63$. These parameter

values imply that almost $80 \%$ of income is spent on tradable commodities. Furthermore,

the small value of $d$ implies that the non-tradable sector has significant decreasing returns

to scale in individual skills, so that it is quite close to relying on just the amount of time provided. $^{11}$

Table 1 presents the results of the calibration exercise for a few selected countries, and in the top row the world average. ${ }^{12}$ (Table A-2 in the appendix shows the results for all 118 countries in the simulation). The first column of Table 1 shows the average labor

${ }^{10}$ There are a few complications in implementing this method. Most importantly, it may not be possible to match the empirical Gini values even by choosing extreme values of the inequality of skills. To see this concern, consider the case when $\delta=0$. In this situation, all individuals employed in the non-tradable sector have exactly the same wage rate and exactly the same income. Because a given fraction of income must be spent on the production of this sector, this requires a big enough fraction of population working in this sector. As the result, the combination of a relatively low value of $\delta$ and a relatively low value of $d$ (i.e., a high share of non-tradables) makes the lower end of the distribution equal and large, therefore limiting the overall level of inequality. It turns out that there is a region of values of these parameters where the actual Gini coefficients for the most unequal countries may not be matched. It also turned out that the best choice of these parameters (i.e., the one that minimizes the deviations from the actual PPP levels) is on the boundary of this region (i.e., the country with the highest inequality level has an extreme inequality of skills). The parameters we use are almost on this boundary, but the results are not sensitive to shifting away from the boundary.

${ }^{11}$ With $d=0, a^{d}=1$, implying that skill would not matter at all in the non-tradable sector. As a result, only hours worked in that sector would determine its output. 
income if everybody worked full-time (i.e., consumed no leisure at all). The following columns show the average labor supply, consumption, and unemployment rate. Unemployment in this model is voluntary, and is a result of the demogrant that implies that a certain degree of consumption is possible even with zero labor supply. Although the simulated unemployment rate is as high as $21 \%$ for a few of the most unequal economies (those with Gini coefficients exceeding 0.55 ; see Table A-2 in the appendix), in aggregate only a tiny fraction (less than $0.5 \%$ ) of the world's population chooses not to work. Those that choose to be unemployed are at the bottom of the ability distribution in a given country. Because with a Cobb-Douglas utility function, richer economies are just scaled-up versions of poorer ones, the unemployment rate is simply a function of the degree of inequality in underlying abilities.

The next two columns show the Gini coefficients of pre-tax labor income and consumption in the baseline simulation. Note that, because of the redistributive nature of the baseline tax system, the former is always higher than the latter, with the difference between the two measures ranging between 5 and 25 points. In each case, the parameters have been selected so that the relevant one of these is equal to the empirical value from Table A-1. The Gini coefficient of consumption for the world as a whole is 0.68 , while the Gini coefficient based on labor income is 0.72 .

The final three columns show consumption levels at the $5^{\text {th }}, 50^{\text {th }}$, and $95^{\text {th }}$ percentiles of the distribution. Huge inequality of consumption is evident in the statistics for the world: median consumption is $\$ 1,814$, while consumption at the $95^{\text {th }}$ percentile is

${ }^{12}$ The world average is computed over all individuals, and is not equal to the unweighted average of the country averages. 
$\$ 27,860$. As Figures A-2 and A-3 show, the calibrated PPP indices quite closely match the actual ones, although this mostly reflects the fact that the dependence of the price level on income is well accounted for. In reality there is also significant variation in the price level conditional on income level, and this is not well explained by our model. There is a small variation of the price level conditional on income that is produced by our model (due to differences in inequality levels), but it is nowhere near what is observed in the data.

\section{Results}

We are now ready to calculate the optimal income tax systems, first for each country and then for the world income tax. Table 2 shows the results for a subset of countries; Table A-3 in the appendix gives the full set of results.

In the focal simulation we assume that the parameter of the Atkinson's welfare function is $v=2.0 .^{13}$ The first and third columns of Table 2 show the parameters marginal tax rate and demogrant - of the decentralized optimal linear income tax. The optimal marginal tax rates are monotonically related to the Gini coefficients shown in Table 1. Under the decentralized solution, the optimal marginal tax rate varies between 0.13 for the Slovak Republic and 0.82 for Gabon. The population-weighted-average marginal tax rate is 0.41 .

\footnotetext{
${ }^{13}$ As we discuss later, the qualitative conclusions are robust to changes in this parameter.
} 
Table 2: Comparison of the decentralized solution and the WIT

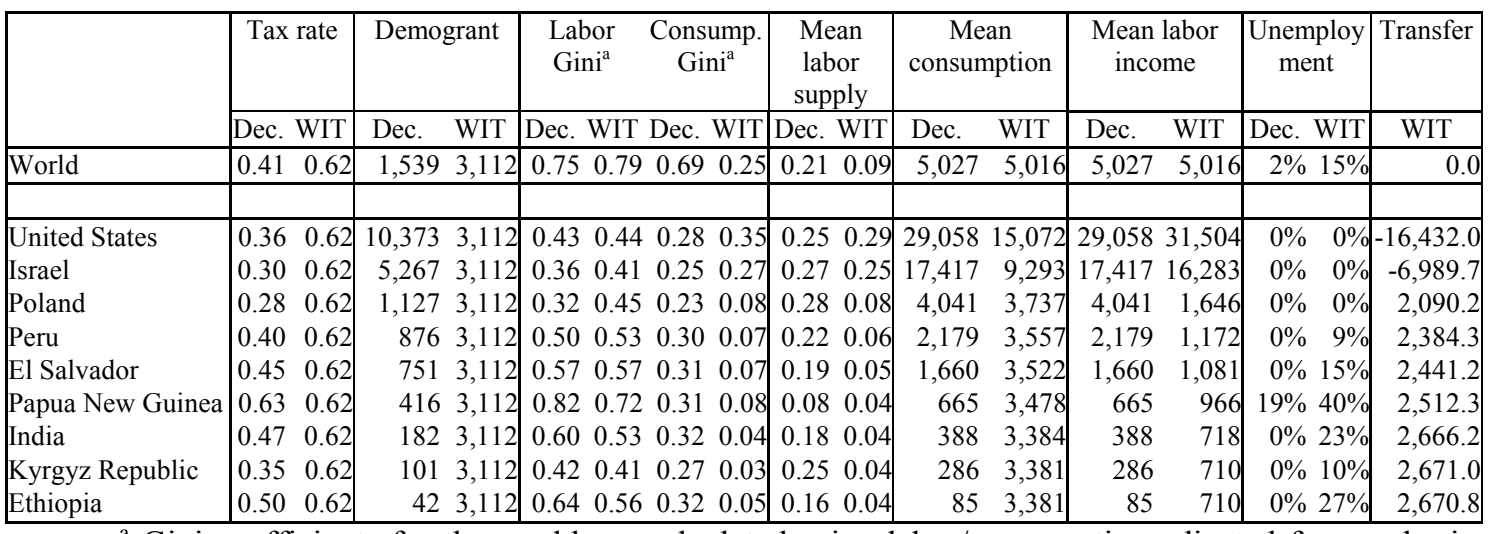

${ }^{\mathrm{a}}$ Gini coefficients for the world are calculated using labor/consumption adjusted for purchasing power parity differences.

The second and fourth columns of Table 2 show the parameters of the optimal world income tax. The marginal tax rate is 0.62 , substantially higher than the average under the decentralized solution, although smaller than the decentralized tax rates for a handful of the most unequal economies. The world income tax system also features a very significant demogrant of $\$ 3,112$. This demogrant exceeds the actual per capita GNP for 73 countries. Note, however, that the aid from abroad backfires as well, because it takes the form of tradable commodities. As a result, the larger the aid, the lower the value of tradables in terms of non-tradables and the less effective is a dollar of transfers.

Because of the monotonic relationship between the Gini and optimal progressivity, the world income tax rate is higher than the rate for almost all countries in the world. For this reason, the deadweight loss is significantly higher than would occur under the decentralized systems. The ratio of deadweight loss to the amount of redistribution achieved is also higher than it need be under a decentralized redistribution scheme. To see why, consider the hypothetical situation where each country has the same Gini but differing levels of mean income, so that each country would on its own choose the same optimal marginal tax. Assume further that the marginal tax rate that the world 
planner would choose is the same, because (we assume) world inequality is approximately the same as in each country. Because each person faces the same marginal tax rate under the decentralized and world income tax systems, the deadweight loss in the two cases would also be identical. However, the world income tax system would accomplish much more redistribution, because it is not providing demogrants to people who are poor from a country's perspective but who are not poor from a world perspective.

The middle four columns of Table 2 show the Gini coefficients of consumption and labor income under the decentralized and world income tax regimes. Not surprisingly, the Gini coefficients of consumption are lower than those of labor income. ${ }^{14}$ Redistributive tax systems render consumption considerably more equal.

A striking result of this simulation is that the decentralized tax system does not substantially affect the degree of inequality for the whole world. The Gini coefficient of consumption decreases only slightly when compared to the original calibrated world featured in Table $1 .{ }^{15}$ In fact, if tax rates in all countries were set to zero, the Gini coefficient of consumption would be 0.695 , compared to just 0.689 under the decentralized tax systems. Each country redistributing on its own makes only a small dent in world inequality. This result simply reflects that inequality in the distribution of all individuals' income, regardless of where in the world they live, is higher than the inequality of individuals' income within nearly every country of the world. According to Milanovic (1999), the differences in countries' mean income explain at least three-

\footnotetext{
${ }^{14}$ In most cases the Gini coefficient of consumption falls below the baseline values of Table 1, for both the decentralized and the world tax systems, with exceptions to this rule being the economies that optimally set taxes below the baseline value of $\mathrm{t}=0.3$.
} 
quarters of overall world inequality. No country on its own can transfer income from the world's rich to the world's poor, because no country has the world's poorest and the world's richest among its citizens. Consequently, decentralized redistribution cannot significantly address world's inequality.

The world income tax fares significantly better in reducing the inequality of consumption. The Gini coefficient goes from 0.69 under the decentralized tax regimes to 0.25 under the WIT, when calculated using consumption adjusted for the (endogenous) price level. However, because of its disincentive effects, the world income tax also decreases the average level of consumption and reduces average labor supply. Average labor supply (the number of hours worked) falls by more than half, from 0.21 to 0.09 , under the world income tax. This decline is mostly due to the sharp decline in labor supply in the poor economies. The world unemployment rate increases from $2 \%$ to $15 \%$.

Although by construction there are no cross-border transfers under the decentralized solution, under the world income tax the implicit transfers are substantial. For example, per capita the United States transfers $\$ 16,432$ abroad. Countries at about the mean income of Uruguay and below receive net transfers, and the poorest countries receive more than $\$ 2,600$ per capita. The mean level of welfare for the whole world ${ }^{16}$ increases under the world income tax system when compared to the decentralized solution, implying that the world income tax is more successful in redistributing income than the decentralized system. Under the decentralized solution, the average welfare level

\footnotetext{
${ }^{15}$ This is possible because for many richer economies our baseline tax rate of 0.3 exceeds the optimal marginal tax rate, and therefore for these countries there is more redistribution in the baseline case than under the optimal income tax structure.

${ }^{16}$ The welfare levels are normalized for expositional purposes. Only relative differences are of interest.
} 
Table 3: Comparison of the decentralized solution and the WIT: Further details

\begin{tabular}{|c|c|c|c|c|c|c|c|c|c|c|c|c|}
\hline & \multirow{2}{*}{\multicolumn{2}{|c|}{\begin{tabular}{|c|} 
Average \\
non-tradable \\
consumption
\end{tabular}}} & \multirow{2}{*}{$\begin{array}{c}\text { Price of non- } \\
\text { tradables }\end{array}$} & \multirow[t]{2}{*}{ PPP } & \multicolumn{6}{|c|}{ Consumption Percentiles $^{\text {a }}$} & \multirow{2}{*}{\multicolumn{2}{|c|}{ Average welfare }} \\
\hline & & & & & \multicolumn{2}{|c|}{$5 \%$} & \multicolumn{2}{|c|}{$50 \%$} & \multicolumn{2}{|c|}{$95 \%$} & & \\
\hline & Dec. & WIT & Dec. $\quad$ WIT & Dec. WIT & Dec. & WIT & Dec. & WIT & Dec. & WIT & Dec. & WIT \\
\hline World & 0.22 & 0.13 & $3,371 \quad 7,687$ & & 566 & 4,962 & 1,599 & 6,198 & 28,784 & 14,043 & $-7,564,213$ & $-4,384,246$ \\
\hline Unit & 0.35 & 0.25 & $17,52512,467$ & 1.001 .00 & 17,373 & 6,835 & 20,198 & 10,808 & 65,683 & 657 & $-2,69$ & $-3,608,738$ \\
\hline Israel & 0.34 & 0.21 & $10,858 \quad 9,250$ & 0.850 .90 & 10,812 & 5,260 & 13,346 & 7,353 & 36,416 & 19,906 & $-3,180,572$ & $-3,932,527$ \\
\hline Poland & 0.28 & 0.14 & $2,992 \quad 5,578$ & 0.570 .69 & 2,566 & 3,261 & 3,216 & 3,531 & 8,097 & 5,195 & $-4,96$ & $-4,422,498$ \\
\hline Peru & 0.25 & 0.13 & $1,869 \quad 5,883$ & $\begin{array}{lll}0.50 & 0.70\end{array}$ & 1,272 & 3,112 & 1,465 & 3,431 & 5,207 & 4,252 & $-5,846,696$ & $-4,458,642$ \\
\hline El Salva & 0.22 & 0.12 & $1,587 \quad 6,105$ & $\begin{array}{lll}0.48 & 0.71\end{array}$ & 955 & 3,112 & 1,120 & 3,399 & 4,082 & 3,945 & $-6,288,349$ & $-4,474,412$ \\
\hline Papua New Guinea & 0.12 & 0.10 & $1,198 \quad 7,525$ & 0.440 .82 & 416 & 3,112 & 480 & 3,233 & 1,251 & 4,256 & $-8,109,220$ & $-4,549,222$ \\
\hline India & 0.18 & 0.10 & $456 \quad 7,100$ & 0.330 .78 & 222 & 3,112 & 263 & 3,327 & 963 & 3,892 & $-9,720,412$ & $-4,542,144$ \\
\hline Kyrgy & 0.20 & 0.10 & 2997,191 & 0.290 .79 & 172 & 3,112 & 201 & 3,362 & 635 & 3,734 & $-10,884,054$ & $-4,549,296$ \\
\hline Ethiopia & 0.14 & 0.08 & 1278,589 & 0.220 .91 & 49 & 3,112 & 58 & 3,311 & 212 & 3,934 & $-15,303,253$ & $-4,609,515$ \\
\hline
\end{tabular}

${ }^{a}$ Consumption percentiles for the world are calculated using consumption adjusted for purchasing parity differences.

in the world is about equal to that of the average Filipino. A conversion to the world income tax brings it to about the level of a typical Czech. Not surprisingly, there are huge welfare gains for residents of the poor countries and substantial welfare losses for residents of the developed economies.

Figure 1 illustrates the implications of switching from decentralized income tax systems to a world income tax by plotting tax as a function of gross income for individuals at the 5th, 50th, and 95th percentiles (under the decentralized system) for three countries: India, Poland, and the United States. For the citizens of the United States, tax due under the world income tax exceeds tax liability under the decentralized tax system for any level of gross income. This is also true for the richest Poles, but most Poles would observe a decrease in tax liability, absent behavioral response. Even the richest Indians gain, although not as much as the poorest ones. The figure also shows that the marginal tax rate increases under the WIT for all three economies. As a result, within each country the richest citizens gain least (or lose most).

The value of the substantial cross-country transfers (for example, citizens of India receive on average a nominal transfer of $\$ 2,666$ ) may seem to be magnified by 
differences in the cost of living in different economies. For example, under the decentralized solution the purchasing power of a dollar in India is magnified by a factor of more than three. However, transfers may take the form of tradables only, so that they are not as beneficial as a pure income transfer would be. This is reflected in significant changes in the cost of living of the poorest economies, which reflect the increased prices of non-tradables. This occurs because, as an economy becomes richer (due to transfers), the demand for non-tradables increases, but their supply is still bounded by the economy's own labor resources. In the case of India, the price of non-tradables under the WIT increases by a factor of twenty, and the overall cost of living increases from 0.33 to 0.78 (Table 3). In fact, one result of this transfer scheme is that most of the poorest economies end up consuming less non-tradable goods. This is because there is an overall decrease in labor supply as the result of the large transfer.

The differences in the cost of living also make it possible for average consumption in the world to stay almost constant in PPP terms. Looking at the percentiles of consumption, it is clear that under the world income tax most of the population gains. The consumption level of the world-median individual increases by $\$ 4,600$ in PPP terms. At the same time, the structure of consumption changes. Consumption of non-tradables falls in every country.

\section{Foreign Aid and the Bono/O'Neill Factor}

A striking feature of the optimal world income tax solution is the large transfers from the rich countries, amounting in the United States to $\$ 16,432$ per capita. In fact, many relatively well-off countries do provide foreign aid to less well-off countries, and 
most rich countries contribute to multilateral institutions such as the World Bank that offer assistance to relatively poor countries. How does it compare to our simulated level of optimal transfers, and what does the comparison imply?

\subsection{Foreign Aid}

The Development Assistance Committee (DAC) of the OECD publishes annual data on both bilateral and multilateral aid flows. ${ }^{17}$ Its 1999 report indicates that in 1998 the U.S. gave $\$ 5.988$ billion of bilateral assistance, and $\$ 2.798$ billion of multilateral assistance, for a total of $\$ 8.786$ billion of official development assistance. This last figure represents $0.10 \%$ of U.S. GNP, and is $\$ 33$ per capita. To put the U.S. figures in perspective, for all 21 DAC countries (including the U.S.), official development assistance represented $0.24 \%$ of GNP; the U.S. ranks 21 st among the 21 countries represented. The actual amount of net aid contributed or received by various countries, from World Bank (2000, Tables 6.8 and 6.10), is presented in the last column of Table A$1^{18}$

${ }^{17}$ There is a considerable literature on the determinants of foreign aid, in particular the extent to which it is motivated by strategic and political considerations as opposed to altruistic and humane ones. Lumsdaine (1997) investigates the effect of colonial links between donor and recipient, the democratic status of the recipients, and the income level of the recipient, but presents only simple correlations rather than a full-blown multivariate analysis. Alesina and Dollar (1998) do perform such an analysis (of bilateral aid flows only), and find considerable evidence that the direction of foreign aid is indeed dictated by political and strategic considerations much more than by either the economic needs or the policy performance of the recipient.

A separate but relevant literature concerns the effects of foreign aid on the receiving countries, and has been studied by Jepma (1997) and Boone (1994, 1996). Most recently, Burnside and Dollar (2000) find that aid is beneficial to countries that adopt appropriate and stable policies, and is wasted otherwise. However, they find no evidence that foreign aid encourages the adoption of "good" macroeconomic policies.

18 Table 6.8 of World Bank (2000) reveals the official development assistance and aid contributions of the high-income economies in 1998. It includes both bilateral transfers and contributions to the financial institutions. Table 6.10 shows the amount of assistance and aid received by various countries. These numbers do not balance out. This is because some aid is allocated by region, but not by country, and because of administrative costs, research into development issues, and aid to non-governmental 


\subsection{Bono and O'Neill: Estimating the Implicit Discounting of Foreigners' Well-being and/or the Implicit Extent of Waste}

The actual flows of aid are miniscule compared to what our simulated world income tax generates. The discrepancy cannot be explained by the efficiency costs that would result from the higher marginal tax rates needed to generate the tax revenue to be transferred from the poor countries - that is an integral part of the WIT simulations. One natural explanation for the discrepancy is that, contrary to the model's assumption, Americans are not border-neutral at all, but rather value the welfare of a foreigner significantly less than the welfare of an American. Another is that transfers are not used efficiently, so that the richer countries perceive them as a waste of resources.

The notion that Americans' altruism stops, or nearly stops, at the border will not shock most readers. Neither will the possibility that transfers are wasted. With the model we have developed, though, we can go beyond suggesting these notions to quantify what the actual flows of aid imply about how much the United States weighs the well-being of a resident of, say, India. Our weights reflect a combination of a lower weight put on foreigners' well-being and the extent of waste. Our preferred interpretation of them is as a measure of the extent to which transfers are wasted that must be implicitly subscribed to if the United States weights citizens of a given country as Americans and yet chooses not to provide substantial aid.

To fix ideas, consider a simple version of this setup in which the U.S. and India are the only countries in the world, and each country has only a poor person (denoted P) and a rich person (denoted R). Each country makes its own decisions about its tax-and-

organizations. As the result, contributions exceed aid received by approximately $\$ 22$ billion. The total 
transfer system. The social welfare function of the U.S. includes the utility level of Indians, although the Indians' utilities may have a relative weight of less than one. The social welfare function of the U.S. has the form $W=(1-v)^{-1}\left[U_{R S}^{1-v}+U_{P S}^{1-v}+b U_{R I}^{1-v}+b U_{P I}^{1-v}\right]$, where $U_{i j}$ refers to the utility of the $i^{\text {th }}$ person in the $j^{\text {th }}$ country ( $\mathrm{S}=\mathrm{US}$ and $\mathrm{I}=$ India), and $b$ $(0<b)$ is the relative weight placed on an Indian's utility.

The United States now has three policy instruments: the demogrant and income tax rate as before, plus a transfer to the Indian government. The U.S. knows the Indian social welfare function, so it knows exactly how India will adjust its own demogrant and tax rate upon receipt of a transfer, and can therefore calculate the increase in the utility of each Indian citizen. Given these assumptions, we can in the framework of our simulated model calculate the amount of transfer to India the U.S. will make for any value of $b$. Conversely, we can work backwards and calculate what value of $b$ is consistent with the amount of transfers we observe. In what follows we do the latter. Before we do so, we introduce the possibility that transfers are wasted. Specifically, we assume that a transfer from the U.S. to any other country need not go toward reducing that country's revenue requirement but instead it can be wasted by corrupt politicians, whose welfare we assign a zero weight. We denote the extent of this waste in country $i$ by $a^{i}$, so that a transfer of $T$ results in a decrease of the revenue requirement by $\left(1-a^{i}\right) \mathrm{T}$.

amount of aid received is about $\$ 35$ billion. 
Table 4: Implied U.S. Weights

\begin{tabular}{|l|c|c|}
\hline & $\begin{array}{c}\text { Decentralized } \\
\text { solution }\end{array}$ & WIT \\
\hline World & 0.1591 & 0.3795 \\
\hline & & \\
\hline United States & 1.0000 & 1.0000 \\
France & 0.8188 & 0.9051 \\
Israel & 0.5284 & 0.6618 \\
Poland & 0.0802 & 0.2933 \\
Peru & 0.0336 & 0.2771 \\
El Salvador & 0.0233 & 0.2725 \\
Papua New Guinea & 0.0071 & 0.2524 \\
India & 0.0035 & 0.2609 \\
Kyrgyz Republic & 0.0024 & 0.2636 \\
Ethiopia & 0.0005 & 0.2557 \\
\hline
\end{tabular}

Calculating the implied weights on the well-being of other countries' residents is straightforward, as long as each country selects its tax system optimally. Denote by $\lambda^{i}$ the marginal social welfare benefit from a marginal increase in public spending in country $i$. Formally, this is the Lagrange multiplier on the revenue constraint in the $i^{\text {th }}$ country's optimal tax problem. ${ }^{19}$ Because of the possibility of waste, the marginal welfare from transfer of a dollar to country $i$ is then $\left(1-a^{i}\right) \lambda^{i}$. On the margin, the optimizing government considering international aid compares its own $\lambda$ to that of other countries. At the optimum, the government of donor country $i$ must then set $\lambda^{i}=\left(1-a^{j}\right) b^{j} \lambda^{j}$, for any recipient country $j$, where $b^{j}$ is the welfare weight attached to country $j$. This formula allows us to calculate the product $\left(1-a^{j}\right) b^{j}$ directly, because optimization yields the values of the $\lambda$ 's. In the case of the model of Section 2, we additionally adjust this formula for differences in the cost of living, so that $b^{j}=p^{i j} \lambda^{i} / \lambda^{j}$, where $p^{i j}$ is the index of cost of living in country $j$ relative to country $i$.

19 At the optimum, it is equal to the average of marginal utilities of income (from the social welfare point of view) in a given country. 
Table 4 presents the implied marginal weights from the point of view of the U.S. for a selected group of countries. By construction, ceteris paribus, weights for the poorer economies must be smaller than those for the richer ones. For the poorest economy of Ethiopia, this weight is just 0.0005 . One blunt interpretation is that the latter number implies that the amount of actual foreign aid given by the U.S. to Ethiopia is consistent with the well-being of an Ethiopia resident being valued at $1 / 2000$ of that of an American. Alternatively, it can be believed that only $1 / 20^{\text {th }}$ of one percent of aid reaches its desired recipients. A combination of the two is also possible. For example, if as much as $5 \%$ of aid reaches its recipients, the corresponding welfare weight consistent with the observed amount of aid would still be equal to just 0.01 .

The column labeled WIT in Table 4 reveals that even under an optimal world income tax there is still room for a potential welfare improvement: the average weight for the rest of the world is 0.4 , so that a marginal dollar in U.S. transfers would still finance a $\$ 2.50$ increase in welfare, if used to finance a universal increase in the demogrant. This is, however, not feasible in our model because of the assumed linearity of the tax system that precludes a unilateral change of the U.S. transfers. ${ }^{20}$

\section{Sensitivity Analyses}

In Table 5, we present the results of simulations analogous to those of Section 3 , but for different degrees of concavity of the common social welfare function. We consider $\mathrm{v}=0.5,2.0$ and 5.0. Because $\mathrm{v}=2.0$ is our baseline case, the numbers in this part

${ }^{20}$ In a more general nonlinear tax system the feasibility of such transfers would be limited by the incentive constraints. 
Table 5: Sensitivity analysis

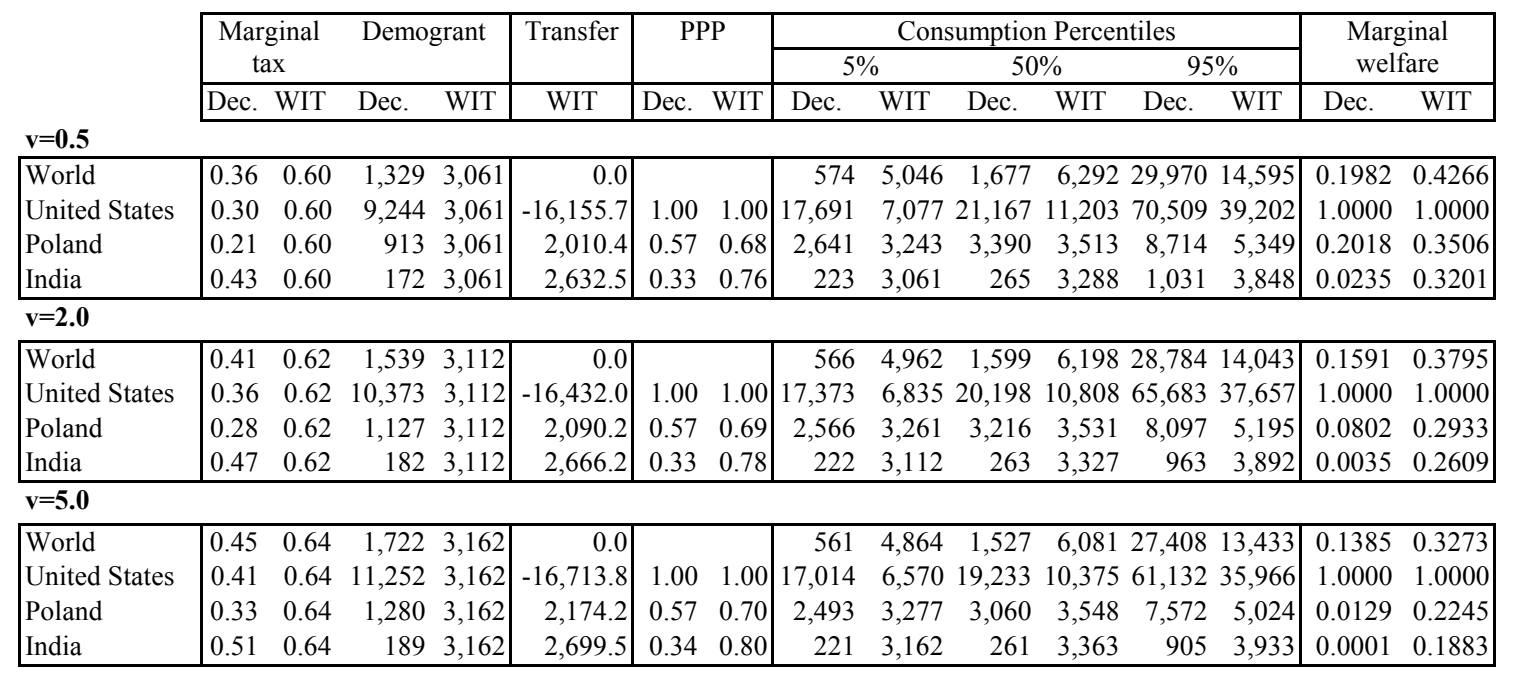

repeat information shown earlier. A value of $\mathrm{v}=5.0$ corresponds to a much more egalitarian social welfare function, while $\mathrm{v}=0.5$ is a much less egalitarian social welfare function. To save space, we show only the results for the world as a whole and three different countries: the United States, Poland and India. As expected, increasing egalitarianism leads to more redistribution: marginal tax rates increase under both the decentralized and world income tax solutions. Notably, though, the changes are much larger in the decentralized case. This is because world inequality is very extreme to begin with, and therefore even a low redistributive incentive induces high marginal tax rates (and the optimal marginal tax rate is bounded from above by the one corresponding to the "peak" of the Laffer curve). Indeed, the optimal world income tax is almost unaffected by changes in the concavity of the welfare function.

Changes in the social welfare function also have significant consequences for the implied weights. This is intuitive. Without any redistributive incentive, these weights would all be equal to one even if the distribution of incomes were very unequal. Therefore, the lower is the concavity of the social welfare function, the higher should be 
these weights. For example, when $v=0.5$, the implied welfare weight attached by the U.S. to an Indian is 0.32 , and it falls to 0.19 for $\mathrm{v}=5.0$.

\section{Summary and Ruminations}

The decentralization of redistribution decisions results in vastly less redistribution than would a centralized world income tax, even if the world policy maker considers the disincentive effects caused by the higher taxes needed for cross-country transfers. In our stylized simulation of redistribution policy, the decentralized system hardly budges the world Gini coefficient of consumption, even though it reduces it for particular countries. Put bluntly, within-country redistributive schemes are of almost no value from the world perspective. In contrast, a world income tax would provide a drastic reduction in consumption inequality, cutting the Gini coefficient by nearly two-thirds. The decentralized scheme is also relatively inefficient, as it causes an efficiency loss that is larger than it need be to achieve the same amount of redistribution as would a centralized system. To be sure, the world income tax features a much higher absolute efficiency cost, because it has a higher marginal tax rate than most countries would choose on their own.

The actual flow of foreign aid is minuscule compared to what the optimal world income tax implies, suggesting that the social policies of the rich countries are not border-neutral, or anything close to that. In our baseline case, we calculate that this level of transfer is consistent with the U.S. on average valuing the well-being of foreigners only $1 / 6$ ths as much as an American citizen, and less than 1/2000th for poorest of the developing economies. Alternatively, it corresponds to an extreme extent of waste so that only $1 / 20^{\text {th }}$ of one percent of transfers reaches its desired recipients. 
This conclusion is sensitive to the assumed concavity of the social welfare function. Furthermore, our interpretation of weights is subject to a number of caveats. The first is due to the restrictiveness of the instruments that we consider: a linear tax does not allow the targeting of aid directly to the poorest members of the poor economies. If more targeted ways of transferring aid were available, the implied weights consistent with actual transfers would be even lower. We consider only a static framework and do not account for the effect that transfers can have on human or physical capital accumulation and, therefore, on future growth. Finally, it would certainly be interesting to credibly distinguish ethnocentrism from perceived inefficiencies. 


\section{References}

Atkinson, Anthony (1970), "The Measurement of Inequality," Journal of Economic Theory, 2.

Atkinson, Anthony (1973), "How Progressive Should Income Tax Be?" In Parkin, Michael, and A.R. Nobay (eds.), Essays in Modern Economics, London, Longman, pp. 90-109.

Auten, Gerald and Robert Carroll (1999), “The Effect of Income Taxes on Household Behavior," Review of Economics and Statistics, 81, 681-693.

Balasa, Bela (1964), “The Purchasing Power Parity Doctrine: A Reappraisal,” Journal of Political Economy, 76, 584-596.

Blundell, Richard and Thomas E. MaCurdy (1999), "Labor Supply: A Review of Alternative Approaches." In Ashenfelter, Orley and David Card, eds., Handbook of Labor Economics, vol. 3, Amsterdam; New York: Elsevier/North Holland.

Boone, Peter (1994), "The Impact of Foreign Aid on Savings and Growth," London School of Economics, mimeo.

Boone, Peter (1996), "Politics and the Effectiveness of Foreign Aid," European Economic Review, 40, 289-329.

Burnside, Craig and David Dollar (2000), "Aid, Policies, and Growth," American Economic Review, 90, 847-68. 
Cooter, Robert and Elhanan Helpman (1976), "Optimal Income Taxation and Transfer Payments Under Different Social Welfare Criteria," Quarterly Journal of Economics, 88, 656-70.

Deininger, Klaus and Lyn Squire (1996), "A New Data Set Measuring Income Inequality," World Bank Economic Review, 10, 565-91.

Gruber, Jonathan and Emmanuel Saez (2000), “The Elasticity of Taxable Income: Evidence and Implications," National Bureau of Economic Research Working Paper No. W7512.

Helpman, Elhanan and Efraim Sadka (1978), "The Optimum Income Tax: Some Comparative Static Results," Journal of Public Economics, 9, 383-93.

Hill, Robert J. (1997), “A Taxonomy of Multilateral Methods for Making International Comparisons of Prices and Quantities," Review of Income and Wealth, 43, 49-69.

Jepma, Catrinus J. (1997), “On the Effectiveness of Development Aid,” World Bank, unpublished.

King, Robert G., Charles I. Plosser and Sergio T. Rebelo (1982), "Production, Growth and Business Cycles: I. The Basic Neoclassical Model," Journal of Monetary Economics, $21,195-232$.

Lumsdaine, David H. (1997), Moral Vision in International Politics, Princeton, NJ: Princeton University Press.

Lydall, Harold F. (1968), The Structure of Earnings, Oxford: Clarendon Press. 
Milanovic, Branko (2002), “True World Income Distribution, 1988 and 1993: First Calculation Based on Household Surveys Alone,” Economic Journal, January, 51-92.

Mirrlees, James A. (1971), "An Exploration in the Theory of Optimum Income Taxation," Review of Economic Studies, 38, 175-208.

OECD (2000), Development Co-operation, 1999 Report, 1, 1.

Rogoff, Kenneth (1996), “The Purchasing Power Parity Puzzle,” Journal of Economic Literature, 72, 647-668.

Sachs, Jeffrey D. (2001), "One-Tenth of 1 Percent to Make the World Safer," Washington Post, November 21, p. A23.

Samuelson, Paul A. (1964), "Theoretical Notes on Trade Problems," Review of Economics and Statistics, 46, 145-154.

Slemrod, Joel (1998), "Methodological Issues in Measuring and Interpreting Taxable Income Elasticities," National Tax Journal, 51, 773-788.

Stern, Nicholas H. (1976), "On the Specification of Models of Optimum Income Taxation," Journal of Public Economics, 6, 123-62.

World Bank (2000), World Development Indicators 2000, Washington, D.C.: World Bank. 
Table A-1: Data

\begin{tabular}{|c|c|c|c|c|c|c|c|c|}
\hline & Country & Population & GNP & GNP (PPP) & PPP deflator & Gini & Year of Gini & Net aid \\
\hline 1 & Luxembourg & 432 & 44,640 & 38,247 & 1.167 & 26.90 & $1994^{9}$ & -115 \\
\hline 2 & Switzerland & 7,120 & 38,350 & 27,486 & 1.395 & 33.10 & $1992^{g}$ & -974 \\
\hline 3 & Norway & 4,454 & 32,880 & 26,522 & 1.240 & 25.80 & $1995^{\mathrm{g}}$ & -1373 \\
\hline 4 & Japan & 126,570 & 32,230 & 24,041 & 1.341 & 24.90 & $1993^{g}$ & -10772 \\
\hline 5 & Denmark & 5,317 & 32,030 & 24,280 & 1.319 & 24.70 & $1992^{g}$ & -1822 \\
\hline 6 & United States & 272,878 & 30,600 & 30,600 & 1.000 & 40.80 & $1997^{\mathrm{g}}$ & -11512 \\
\hline 7 & Singapore & 3,223 & 29,610 & 27,024 & 1.096 & 39.00 & $1989^{g, d}$ & 2 \\
\hline 8 & Austria & 8,086 & 25,970 & 23,808 & 1.091 & 23.10 & $1987^{g}$ & -647 \\
\hline 9 & Germany & 82,027 & 25,350 & 22,404 & 1.131 & 30.00 & $1994^{\mathrm{g}}$ & -6235 \\
\hline 10 & Sweden & 8,857 & 25,040 & 20,824 & 1.202 & 25.00 & $1992^{g}$ & -1678 \\
\hline 11 & Belgium & 10,223 & 24,510 & 24,200 & 1.013 & 25.00 & $1992^{\mathrm{g}}$ & -951 \\
\hline 12 & Netherlands & 15,802 & 24,320 & 23,052 & 1.055 & 32.60 & $1994^{g}$ & -3172 \\
\hline 13 & Finland & 5,167 & 23,780 & 21,209 & 1.121 & 25.60 & $1991^{\mathrm{g}}$ & -478 \\
\hline 14 & Hong Kong & 6,877 & 23,520 & 20,939 & 1.123 & 45.00 & $1991^{\mathrm{g}, \mathrm{d}}$ & 7 \\
\hline 15 & France & 60,794 & 23,480 & 21,897 & 1.072 & 32.70 & $1995^{\mathrm{g}}$ & -6565 \\
\hline 16 & United Kingdom & 59,110 & 22,640 & 20,883 & 1.084 & 36.10 & $1991^{\mathrm{g}}$ & -4299 \\
\hline 17 & Australia & 18,994 & 20,050 & 22,448 & 0.893 & 35.20 & $1994^{\mathrm{g}}$ & -961 \\
\hline 18 & Italy & 57,649 & 19,710 & 20,751 & 0.950 & 27.30 & $1995^{\mathrm{g}}$ & -2521 \\
\hline 19 & Canada & 30,604 & 19,320 & 23,725 & 0.814 & 31.50 & $1994^{\mathrm{g}}$ & -1848 \\
\hline 20 & Ireland & 3,727 & 19,160 & 19,180 & 0.999 & 35.90 & $1987^{g}$ & -199 \\
\hline 21 & Israel & 6,093 & 17,450 & 16,867 & 1.035 & 35.50 & $1992^{g}$ & 1066 \\
\hline 22 & Spain & 39,410 & 14,000 & 16,730 & 0.837 & 32.50 & $1990^{\mathrm{g}}$ & -1381 \\
\hline 23 & New Zealand & 3,823 & 13,780 & 16,566 & 0.832 & 43.90 & $1993^{g}$ & -130 \\
\hline 24 & Greece & 10,536 & 11,770 & 14,595 & 0.806 & 32.70 & $1993^{g}$ & -179 \\
\hline 25 & Portugal & 9,990 & 10,600 & 15,147 & 0.700 & 35.60 & $1994-95^{g}$ & -279 \\
\hline 26 & Slovenia & 1,981 & 9,890 & 15,062 & 0.657 & 26.80 & $1995^{\mathrm{g}}$ & 40 \\
\hline 27 & Korea Republic & 46,848 & 8,490 & 14,637 & 0.580 & 31.60 & $1993^{c}$ & -50 \\
\hline 28 & Uruguay & 3,312 & 5,900 & 8,280 & 0.713 & 42.30 & $1989^{g}$ & 24 \\
\hline 29 & Czech Republic & 10,280 & 5,060 & 12,289 & 0.412 & 25.40 & $1996^{\mathrm{g}}$ & 447 \\
\hline 30 & Chile & 15,018 & 4,740 & 8,370 & 0.566 & 56.50 & $1994^{\mathrm{g}}$ & 105 \\
\hline 31 & Hungary & 10,068 & 4,650 & 10,479 & 0.444 & 30.80 & $1996^{g}$ & 209 \\
\hline 32 & Croatia & 4,464 & 4,580 & 6,915 & 0.662 & 26.80 & $1998^{c}$ & 39 \\
\hline 33 & Brazil & 168,066 & 4,420 & 6,317 & 0.700 & 60.00 & $1996^{g}$ & 329 \\
\hline 34 & Mexico & 97,425 & 4,400 & 7,719 & 0.570 & 53.70 & $1995^{\mathrm{g}}$ & 15 \\
\hline 35 & Trinidad and Tobago & 1,293 & 4,390 & 7,262 & 0.605 & 40.30 & $1992^{\mathrm{g}}$ & 14 \\
\hline 36 & Poland & 38,695 & 3,960 & 7,894 & 0.502 & 32.90 & $1996^{g}$ & 902 \\
\hline 37 & Venezuela & 23,707 & 3,670 & 5,268 & 0.697 & 48.80 & $1996^{g}$ & 37 \\
\hline 38 & Slovak Republic & 5,396 & 3,590 & 9,811 & 0.366 & 19.50 & $1992^{\mathrm{g}}$ & 155 \\
\hline 39 & Mauritius & 1,170 & 3,590 & 8,652 & 0.415 & 36.69 & $1991^{\mathrm{c}, \mathrm{d}}$ & 40 \\
\hline 40 & Estonia & 1,442 & 3,480 & 7,826 & 0.445 & 35.40 & $1995^{\mathrm{g}}$ & 90 \\
\hline 41 & Malaysia & 22,710 & 3,400 & 7,963 & 0.427 & 48.50 & $1995^{\mathrm{g}}$ & 202 \\
\hline 42 & Gabon & 1,208 & 3,350 & 5,325 & 0.629 & 63.18 & $1977^{c, d}$ & 45 \\
\hline 43 & Botswana & 1,588 & 3,240 & 6,032 & 0.537 & 54.21 & $1986^{c, d}$ & 106 \\
\hline 44 & South Africa & 21,429 & 3,160 & 8,318 & 0.380 & 59.30 & $1993-94^{c}$ & 512 \\
\hline 45 & Panama & 2,808 & 3,070 & 5,016 & 0.612 & 48.50 & $1997^{c}$ & 22 \\
\hline 46 & Turkey & 64,328 & 2,900 & 6,126 & 0.473 & 41.50 & $1994^{c}$ & 14 \\
\hline 47 & Costa Rica & 3,588 & 2,740 & 5,770 & 0.475 & 47.00 & $1996^{g}$ & 27 \\
\hline 48 & Belarus & 10,208 & 2,630 & 6,518 & 0.403 & 21.70 & $1998^{c}$ & 28 \\
\hline 49 & Lithuania & 3,699 & 2,620 & 6,093 & 0.430 & 32.40 & $1996^{c}$ & 128 \\
\hline 50 & Latvia & 2,430 & 2,470 & 5,938 & 0.416 & 32.40 & $1998^{g}$ & 97 \\
\hline 51 & Peru & 25,230 & 2,390 & 4,387 & 0.545 & 46.20 & $1996^{g}$ & 501 \\
\hline 52 & Jamaica & 2,598 & 2,330 & 3,276 & 0.711 & 36.40 & $1996^{c}$ & 18 \\
\hline 53 & Russian Federation & 146,512 & 2,270 & 6,339 & 0.358 & 48.70 & $1998^{c}$ & 1017 \\
\hline 54 & Colombia & 41,539 & 2,250 & 5,709 & 0.394 & 57.10 & $1996^{g}$ & 166 \\
\hline 55 & Tunisia & 9,457 & 2,100 & 5,478 & 0.383 & 40.20 & $1990^{c}$ & 148 \\
\hline 56 & Thailand & 61,691 & 1,960 & 5,599 & 0.350 & 41.40 & $1998^{c}$ & 690 \\
\hline 57 & Dominican Republic & 8,404 & 1,910 & 4,653 & 0.410 & 48.70 & $1996^{g}$ & 120 \\
\hline 58 & EI Salvador & 6,189 & 1,900 & 4,048 & 0.469 & 52.30 & $1996^{g}$ & 180 \\
\hline 59 & Iran & 62,977 & 1,760 & 5,163 & 0.341 & 42.90 & $1984^{c}$ & 164 \\
\hline 60 & Guatemala & 11,086 & 1,660 & 3,517 & 0.472 & 59.60 & $1989^{g}$ & 233 \\
\hline 61 & Paraguay & 5,359 & 1,580 & 4,193 & 0.377 & 59.10 & $1995^{\mathrm{g}}$ & 76 \\
\hline 62 & Algeria & 29,950 & 1,550 & 4,753 & 0.326 & 35.30 & $1995^{c}$ & 389 \\
\hline
\end{tabular}


Table A-1: Data

\begin{tabular}{|c|c|c|c|c|c|c|c|c|}
\hline & Country & Population & GNP & GNP (PPP) & PPP deflator & Gini & Year of Gini & Net aid \\
\hline 63 & Romania & 22,458 & 1,520 & 5,647 & 0.269 & 28.20 & $1994^{9}$ & 356 \\
\hline 64 & Jordan & 4,693 & 1,500 & 3,542 & 0.423 & 36.40 & $1997^{c}$ & 408 \\
\hline 65 & Egypt & 62,430 & 1,400 & 3,303 & 0.424 & 28.90 & $1995^{c}$ & 1915 \\
\hline 66 & Bulgaria & 8,216 & 1,380 & 4,914 & 0.281 & 28.30 & $1995^{c}$ & 232 \\
\hline 67 & Ecuador & 12,409 & 1,310 & 2,605 & 0.503 & 43.70 & $1995^{c}$ & 176 \\
\hline 68 & Kazakhstan & 15,438 & 1,230 & 4,408 & 0.279 & 35.40 & $1996^{c}$ & 207 \\
\hline 69 & Morocco & 28,238 & 1,200 & 3,190 & 0.376 & 39.50 & $1998-99^{c}$ & 528 \\
\hline 70 & Philippines & 76,785 & 1,020 & 3,815 & 0.267 & 46.20 & $1997^{c}$ & 607 \\
\hline 71 & Bolivia & 8,135 & 1,010 & 2,193 & 0.461 & 42.00 & $1990^{g}$ & 628 \\
\hline 72 & Sri Lanka & 18,985 & 820 & 3,056 & 0.268 & 34.40 & $1995^{c}$ & 490 \\
\hline 73 & Papua New Guinea & 4,705 & 800 & 2,263 & 0.354 & 50.90 & $1996^{c}$ & 361 \\
\hline 74 & China & $1,249,671$ & 780 & 3,291 & 0.237 & 40.30 & $1998^{g}$ & 2359 \\
\hline 75 & Honduras & 6,325 & 760 & 2,254 & 0.337 & 53.70 & $1996^{g}$ & 318 \\
\hline 76 & Ukraine & 49,908 & 750 & 3,142 & 0.239 & 32.50 & $1996^{c}$ & 380 \\
\hline 77 & Uzbekistan & 24,600 & 720 & 2,092 & 0.344 & 33.30 & $1993^{g}$ & 144 \\
\hline 78 & Cote d'Ivoire & 14,729 & 710 & 1,546 & 0.459 & 36.70 & $1995^{c}$ & 798 \\
\hline 79 & Turkmenistan & 4,779 & 660 & 3,099 & 0.213 & 40.80 & $1998^{c}$ & 17 \\
\hline 80 & Cameroon & 14,691 & 580 & 1,444 & 0.402 & 49.00 & $1983^{c, d}$ & 424 \\
\hline 81 & Indonesia & 207,022 & 580 & 2,439 & 0.238 & 36.50 & $1996^{g}$ & 1258 \\
\hline 82 & Lesotho & 2,105 & 550 & 2,058 & 0.267 & 56.00 & $1986-87^{c}$ & 66 \\
\hline 83 & Zimbabwe & 11,904 & 520 & 2,470 & 0.211 & 56.80 & $1990-91^{c}$ & 280 \\
\hline 84 & Guinea & 7,247 & 510 & 1,761 & 0.290 & 40.30 & $1994^{c}$ & 359 \\
\hline 85 & Senegal & 9,285 & 510 & 1,341 & 0.380 & 41.30 & $1995^{c}$ & 502 \\
\hline 86 & Armenia & 3,809 & 490 & 2,210 & 0.222 & 39.39 & $1989^{g, d}$ & 138 \\
\hline 87 & Pakistan & 134,790 & 470 & 1,757 & 0.268 & 31.20 & $1996-97^{c}$ & 1050 \\
\hline 88 & India & 997,515 & 450 & 2,149 & 0.209 & 37.80 & $1997^{c}$ & 1595 \\
\hline 89 & Nicaragua & 4,919 & 430 & 2,154 & 0.200 & 50.30 & $1991^{c}$ & 562 \\
\hline 90 & Ghana & 18,949 & 390 & 1,793 & 0.218 & 32.70 & $1997^{c}$ & 701 \\
\hline 91 & Mauritania & 2,598 & 380 & 1,522 & 0.250 & 38.90 & $1995^{c}$ & 171 \\
\hline 92 & Vietnam & 77,515 & 370 & 1,755 & 0.211 & 36.10 & $1998^{c}$ & 1163 \\
\hline 93 & Bangladesh & 127,669 & 370 & 1,475 & 0.251 & 33.60 & $1995-96^{c}$ & 1251 \\
\hline 94 & Moldova & 4,281 & 370 & 2,358 & 0.157 & 34.40 & $1992^{\mathrm{g}}$ & 33 \\
\hline 95 & Kenya & 29,410 & 360 & 975 & 0.369 & 44.50 & $1994^{c}$ & 474 \\
\hline 96 & Yemen & 17,048 & 350 & 688 & 0.509 & 39.50 & $1992^{c}$ & 310 \\
\hline 97 & Mongolia & 2,623 & 350 & 1,496 & 0.234 & 33.20 & $1995^{c}$ & 203 \\
\hline 98 & Gambia & 1,251 & 340 & 1,492 & 0.228 & 47.80 & $1992^{c}$ & 38 \\
\hline 99 & Sudan & 28,993 & 330 & 1,298 & 0.254 & 38.72 & $1968^{g, a}$ & 209 \\
\hline 100 & Uganda & 21,479 & 320 & 1,136 & 0.282 & 39.20 & $1992-93^{c}$ & 471 \\
\hline 101 & Zambia & 9,881 & 320 & 686 & 0.466 & 49.80 & $1996^{c}$ & 349 \\
\hline 102 & Nigeria & 123,897 & 310 & 744 & 0.417 & 50.60 & $1996-97^{c}$ & 204 \\
\hline 103 & Kyrgyz Republic & 4,744 & 300 & 2,223 & 0.135 & 40.50 & $1997^{\mathrm{g}}$ & 216 \\
\hline 104 & Central African Republic & 3,540 & 290 & 1,131 & 0.256 & 61.30 & $1993^{c}$ & 120 \\
\hline 105 & Lao PDR & 5,097 & 280 & 1,726 & 0.162 & 30.40 & $1992^{c}$ & 281 \\
\hline 106 & Cambodia & 11,757 & 260 & 1,286 & 0.202 & 40.40 & $1997^{c}$ & 337 \\
\hline 107 & Madagascar & 15,051 & 250 & 766 & 0.326 & 46.00 & $1993^{c}$ & 494 \\
\hline 108 & Tanzania & 32,923 & 240 & 478 & 0.502 & 38.20 & $1993^{c}$ & 998 \\
\hline 109 & Mali & 10,911 & 240 & 693 & 0.346 & 50.50 & $1994^{c}$ & 349 \\
\hline 110 & Burkina Faso & 10,996 & 240 & 898 & 0.267 & 48.20 & $1994^{c}$ & 397 \\
\hline 111 & Mozambique & 17,264 & 230 & 797 & 0.289 & 39.60 & $1996-97^{c}$ & 1039 \\
\hline 112 & Nepal & 23,384 & 220 & 1,219 & 0.180 & 36.70 & $1995-96^{c}$ & 404 \\
\hline 113 & Malawi & 10,788 & 190 & 581 & 0.327 & 62.00 & $1993^{c, d}$ & 434 \\
\hline 114 & Niger & 10,493 & 190 & 727 & 0.261 & 50.50 & $1995^{c}$ & 291 \\
\hline 115 & Guinea-Bissau & 1,185 & 160 & 595 & 0.269 & 56.20 & $1991^{c}$ & 96 \\
\hline 116 & Sierra Leone & 4,949 & 130 & 414 & 0.314 & 62.90 & $1989^{c}$ & 106 \\
\hline 117 & Burundi & 6,678 & 120 & 553 & 0.217 & 33.30 & $1992^{c}$ & 77 \\
\hline 118 & Ethiopia & 62,782 & 100 & 599 & 0.167 & 40.00 & $1991^{c}$ & 648 \\
\hline
\end{tabular}

c Gini coefficient based on consumption or net income data.

g Gini coefficient based on gross income data.

d Value of Gini from Deininger and Squire (1996).

Population in thousands, GNP in PPP dollars per capita, net aid in billions of nominal dollars. 
Table A-2 - Baseline Tax System - Decentralized 30\% Income Tax

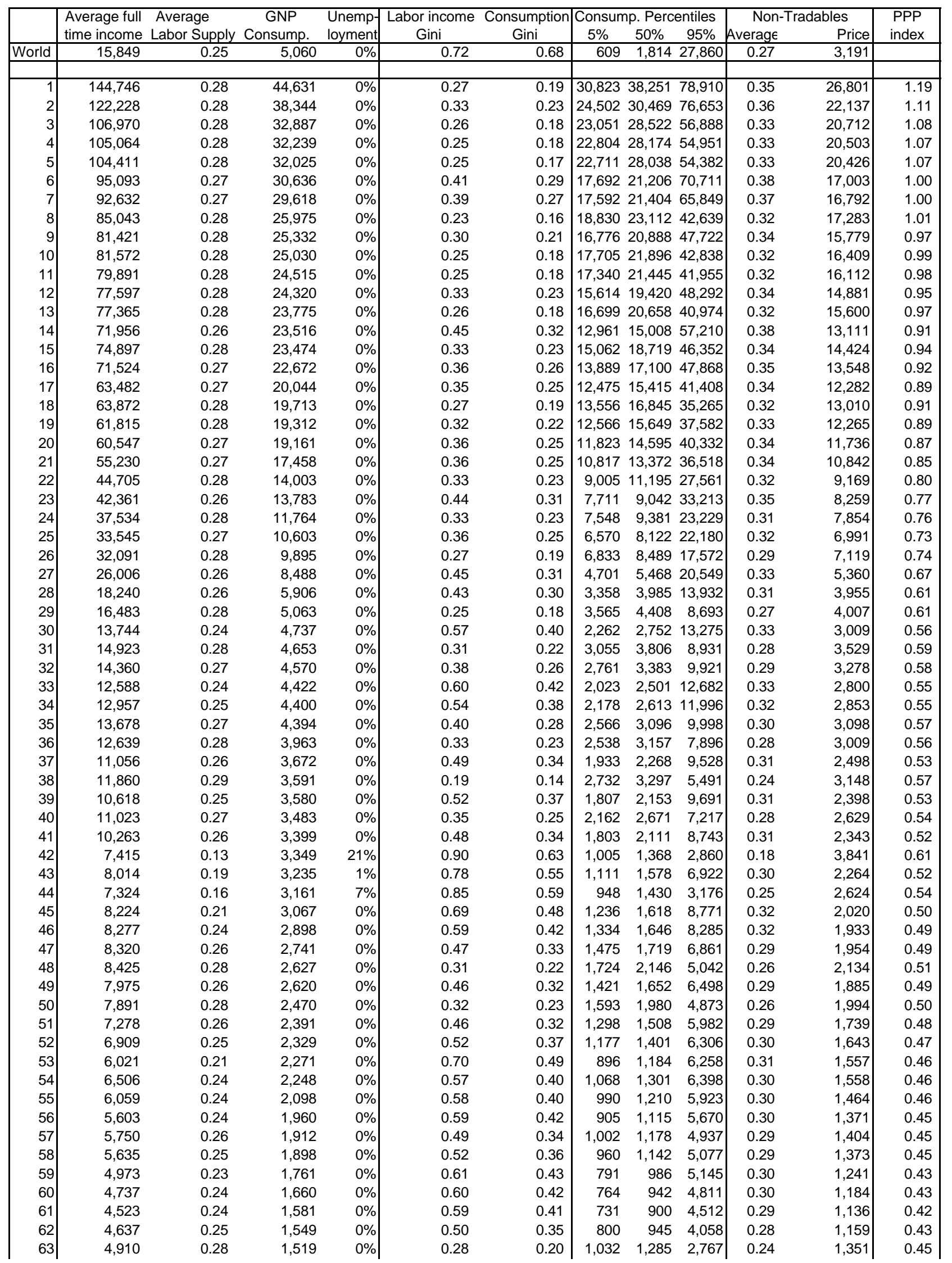


Table A-2 - Baseline Tax System - Decentralized 30\% Income Tax

\begin{tabular}{|c|c|c|c|c|c|c|c|c|c|c|c|c|}
\hline & \multirow{2}{*}{$\begin{array}{l}\text { Average full } \\
\text { time income }\end{array}$} & \multirow{2}{*}{$\begin{array}{l}\text { Average } \\
\text { Labor Supply }\end{array}$} & \multirow{2}{*}{$\begin{array}{c}\text { GNP } \\
\text { Consump. }\end{array}$} & \multirow{2}{*}{$\begin{array}{l}\text { Unemp- } \\
\text { loyment }\end{array}$} & \multirow{2}{*}{$\begin{array}{l}\text { Labor income } \\
\text { Gini }\end{array}$} & \multirow{2}{*}{$\begin{array}{c}\text { Consumption } \\
\text { Gini }\end{array}$} & \multicolumn{3}{|c|}{ Consump. Percentiles } & \multicolumn{2}{|c|}{ Non-Tradables } & \multirow{2}{*}{$\begin{array}{l}\text { PPP } \\
\text { index }\end{array}$} \\
\hline & & & & & & & $5 \%$ & $50 \%$ & $95 \%$ & Averag $\epsilon$ & Price & \\
\hline 64 & 4,449 & 0.25 & 1,498 & $0 \%$ & 0.52 & 0.36 & 758 & 902 & 4,008 & 0.28 & 1,115 & 0.42 \\
\hline 65 & 4,339 & 0.27 & 1,395 & $0 \%$ & 0.41 & 0.29 & 811 & 975 & 3,170 & 0.26 & 1,127 & 0.42 \\
\hline 66 & 4,296 & 0.27 & 1,381 & $0 \%$ & 0.41 & 0.28 & 804 & 968 & 3,128 & 0.26 & 1,117 & 0.42 \\
\hline 67 & 3,674 & 0.23 & 1,310 & $0 \%$ & 0.62 & 0.44 & 580 & 727 & 3,843 & 0.29 & 955 & 0.40 \\
\hline 68 & 3,675 & 0.25 & 1,230 & $0 \%$ & 0.51 & 0.35 & 633 & 749 & 3,234 & 0.27 & 944 & 0.40 \\
\hline 69 & 3,480 & 0.24 & 1,199 & $0 \%$ & 0.57 & 0.40 & 573 & 697 & 3,361 & 0.28 & 898 & 0.40 \\
\hline 70 & 2,792 & 0.22 & 1,022 & $0 \%$ & 0.66 & 0.46 & 428 & 550 & 2,937 & 0.28 & 766 & 0.38 \\
\hline 71 & 3,129 & 0.27 & 1,011 & $0 \%$ & 0.42 & 0.29 & 578 & 688 & 2,348 & 0.25 & 840 & 0.39 \\
\hline 72 & 2,463 & 0.26 & 817 & $0 \%$ & 0.49 & 0.34 & 430 & 505 & 2,097 & 0.26 & 666 & 0.36 \\
\hline 73 & 2,084 & 0.20 & 801 & $0 \%$ & 0.73 & 0.51 & 304 & 410 & 2,143 & 0.27 & 629 & 0.36 \\
\hline 74 & 2,428 & 0.27 & 780 & $0 \%$ & 0.40 & 0.28 & 455 & 549 & 1,775 & 0.24 & 677 & 0.37 \\
\hline 75 & 2,237 & 0.25 & 760 & $0 \%$ & 0.54 & 0.38 & 376 & 451 & 2,093 & 0.26 & 608 & 0.35 \\
\hline 76 & 2,285 & 0.26 & 753 & $0 \%$ & 0.47 & 0.33 & 405 & 472 & 1,884 & 0.25 & 627 & 0.36 \\
\hline 77 & 2,293 & 0.28 & 720 & $0 \%$ & 0.33 & 0.23 & 459 & 570 & 1,443 & 0.23 & 669 & 0.36 \\
\hline 78 & 2,098 & 0.25 & 709 & $0 \%$ & 0.53 & 0.37 & 356 & 425 & 1,934 & 0.26 & 575 & 0.35 \\
\hline 79 & 1,900 & 0.24 & 660 & $0 \%$ & 0.58 & 0.41 & 310 & 379 & 1,868 & 0.26 & 528 & 0.34 \\
\hline 80 & 1,543 & 0.21 & 580 & $0 \%$ & 0.70 & 0.49 & 230 & 303 & 1,607 & 0.26 & 468 & 0.33 \\
\hline 81 & 1,830 & 0.27 & 581 & $0 \%$ & 0.37 & 0.26 & 355 & 437 & 1,237 & 0.23 & 538 & 0.34 \\
\hline 82 & 1,336 & 0.18 & 550 & $2 \%$ & 0.80 & 0.56 & 181 & 263 & 999 & 0.24 & 491 & 0.33 \\
\hline 83 & 1,252 & 0.17 & 521 & $3 \%$ & 0.81 & 0.57 & 166 & 246 & 852 & 0.23 & 480 & 0.33 \\
\hline 84 & 1,473 & 0.24 & 511 & $0 \%$ & 0.58 & 0.40 & 241 & 294 & 1,443 & 0.25 & 422 & 0.32 \\
\hline 85 & 1,460 & 0.24 & 510 & $0 \%$ & 0.59 & 0.41 & 236 & 290 & 1,472 & 0.26 & 419 & 0.32 \\
\hline 86 & 1,533 & 0.27 & 491 & $0 \%$ & 0.39 & 0.28 & 290 & 352 & 1,090 & 0.23 & 454 & 0.32 \\
\hline 87 & 1,443 & 0.26 & 471 & $0 \%$ & 0.45 & 0.31 & 261 & 304 & 1,146 & 0.24 & 421 & 0.32 \\
\hline 88 & 1,319 & 0.25 & 449 & $0 \%$ & 0.54 & 0.38 & 221 & 266 & 1,230 & 0.25 & 382 & 0.31 \\
\hline 89 & 1,126 & 0.20 & 432 & $0 \%$ & 0.72 & 0.51 & 165 & 221 & 1,163 & 0.25 & 365 & 0.30 \\
\hline 90 & 1,188 & 0.26 & 391 & $0 \%$ & 0.47 & 0.33 & 211 & 246 & 974 & 0.23 & 353 & 0.30 \\
\hline 91 & 1,110 & 0.24 & 380 & $0 \%$ & 0.56 & 0.39 & 184 & 223 & 1,068 & 0.24 & 328 & 0.29 \\
\hline 92 & 1,101 & 0.25 & 370 & $0 \%$ & 0.52 & 0.36 & 188 & 224 & 997 & 0.24 & 326 & 0.29 \\
\hline 93 & 1,119 & 0.26 & 370 & $0 \%$ & 0.48 & 0.34 & 197 & 230 & 950 & 0.23 & 333 & 0.30 \\
\hline 94 & 1,175 & 0.27 & 370 & $0 \%$ & 0.35 & 0.24 & 232 & 288 & 760 & 0.21 & 368 & 0.31 \\
\hline 95 & 1,000 & 0.23 & 360 & $0 \%$ & 0.64 & 0.45 & 156 & 198 & 1,056 & 0.25 & 306 & 0.29 \\
\hline 96 & 1,016 & 0.24 & 350 & $0 \%$ & 0.57 & 0.40 & 167 & 203 & 981 & 0.24 & 304 & 0.29 \\
\hline 97 & 1,061 & 0.26 & 351 & $0 \%$ & 0.48 & 0.33 & 187 & 219 & 888 & 0.23 & 318 & 0.29 \\
\hline 98 & 917 & 0.22 & 340 & $0 \%$ & 0.68 & 0.48 & 139 & 180 & 981 & 0.25 & 291 & 0.28 \\
\hline 99 & 1,032 & 0.27 & 330 & $0 \%$ & 0.39 & 0.27 & 197 & 240 & 729 & 0.22 & 321 & 0.29 \\
\hline 100 & 932 & 0.24 & 320 & $0 \%$ & 0.56 & 0.39 & 154 & 187 & 905 & 0.24 & 282 & 0.28 \\
\hline 101 & 842 & 0.21 & 320 & $0 \%$ & 0.71 & 0.50 & 124 & 165 & 867 & 0.24 & 278 & 0.28 \\
\hline 102 & 811 & 0.20 & 310 & $0 \%$ & 0.72 & 0.50 & 119 & 159 & 841 & 0.24 & 272 & 0.28 \\
\hline 103 & 934 & 0.27 & 300 & $0 \%$ & 0.41 & 0.28 & 175 & 210 & 680 & 0.22 & 292 & 0.28 \\
\hline 104 & 653 & 0.14 & 289 & $14 \%$ & 0.88 & 0.61 & 87 & 125 & 235 & 0.16 & 374 & 0.31 \\
\hline 105 & 861 & 0.26 & 280 & $0 \%$ & 0.44 & 0.31 & 157 & 184 & 665 & 0.22 & 268 & 0.28 \\
\hline 106 & 749 & 0.24 & 260 & $0 \%$ & 0.58 & 0.40 & 122 & 149 & 744 & 0.23 & 233 & 0.26 \\
\hline 107 & 685 & 0.22 & 250 & $0 \%$ & 0.66 & 0.46 & 106 & 135 & 731 & 0.24 & 221 & 0.26 \\
\hline 108 & 703 & 0.25 & 240 & $0 \%$ & 0.55 & 0.38 & 118 & 142 & 668 & 0.23 & 220 & 0.26 \\
\hline 109 & 627 & 0.20 & 240 & $0 \%$ & 0.72 & 0.50 & 92 & 123 & 639 & 0.23 & 217 & 0.26 \\
\hline 110 & 643 & 0.21 & 240 & $0 \%$ & 0.69 & 0.48 & 97 & 126 & 686 & 0.24 & 214 & 0.26 \\
\hline 111 & 668 & 0.24 & 230 & $0 \%$ & 0.57 & 0.40 & 110 & 134 & 653 & 0.23 & 210 & 0.26 \\
\hline 112 & 649 & 0.25 & 219 & $0 \%$ & 0.52 & 0.37 & 111 & 132 & 592 & 0.22 & 205 & 0.25 \\
\hline 113 & 425 & 0.14 & 190 & $16 \%$ & 0.88 & 0.62 & 57 & 80 & 157 & 0.15 & 274 & 0.28 \\
\hline 114 & 496 & 0.20 & 190 & $0 \%$ & 0.72 & 0.50 & 73 & 97 & 505 & 0.23 & 176 & 0.24 \\
\hline 115 & 388 & 0.18 & 160 & $2 \%$ & 0.80 & 0.56 & 52 & 76 & 289 & 0.20 & 167 & 0.24 \\
\hline 116 & 288 & 0.13 & 130 & $21 \%$ & 0.90 & 0.63 & 39 & 53 & 112 & 0.12 & 220 & 0.26 \\
\hline 117 & 363 & 0.26 & 120 & $0 \%$ & 0.48 & 0.33 & 64 & 75 & 306 & 0.20 & 124 & 0.21 \\
\hline 118 & 289 & 0.24 & 100 & $0 \%$ & 0.57 & 0.40 & 47 & 58 & 285 & 0.21 & 101 & 0.20 \\
\hline
\end{tabular}


Table A-3a - Comparison of the Optimal Decentralized and World Taxes, v=2.0.

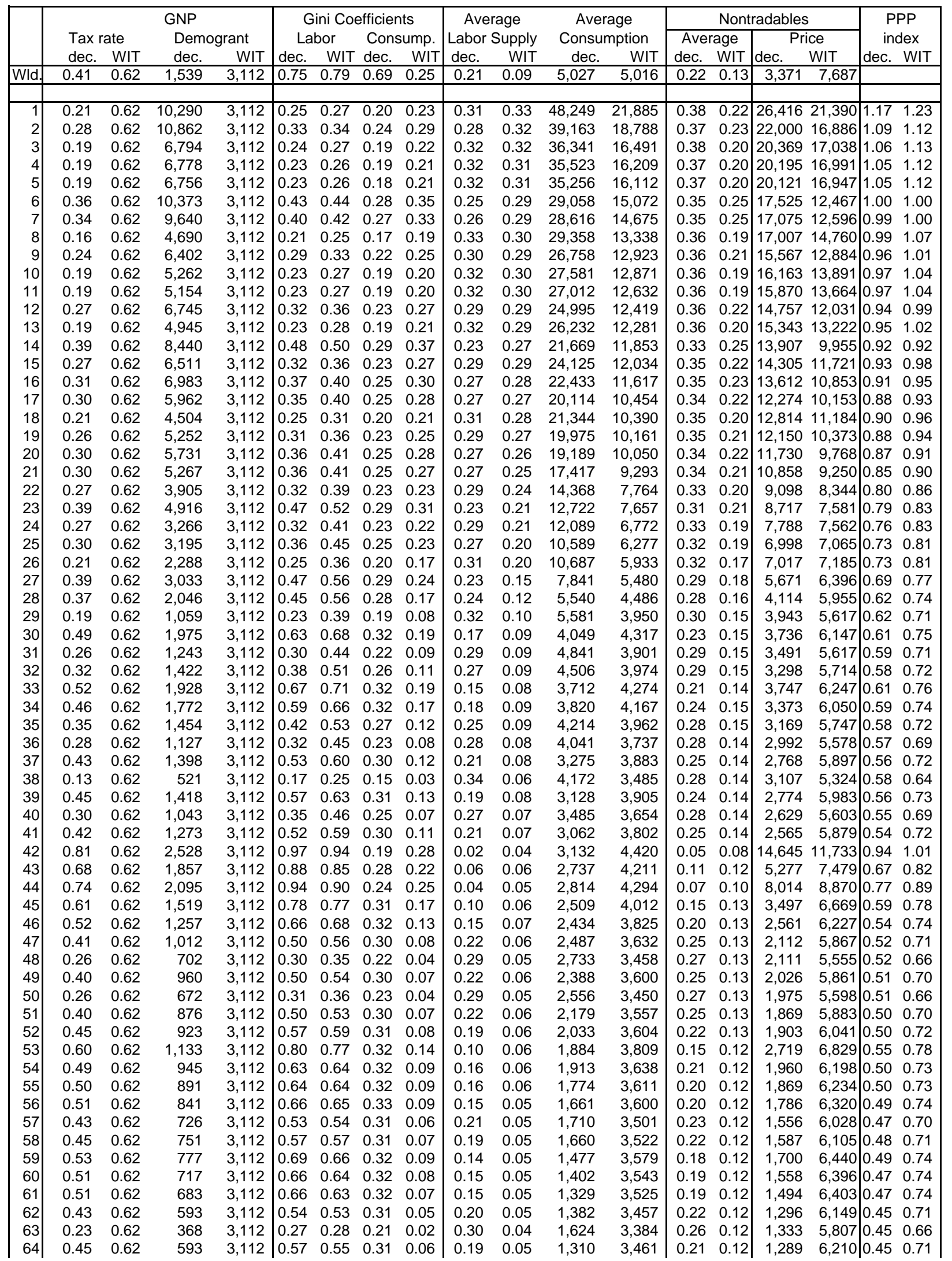


Table A-3a - Comparison of the Optimal Decentralized and World Taxes, v=2.0.

\begin{tabular}{|c|c|c|c|c|c|c|c|c|c|c|c|c|c|c|c|c|c|c|}
\hline & \multicolumn{4}{|c|}{ GNP } & \multicolumn{4}{|c|}{ Gini Coefficients } & \multirow{2}{*}{\multicolumn{2}{|c|}{$\begin{array}{c}\text { Average } \\
\text { Labor Supply }\end{array}$}} & \multirow{2}{*}{\multicolumn{2}{|c|}{$\begin{array}{c}\text { Average } \\
\text { Consumption }\end{array}$}} & \multicolumn{4}{|c|}{ Nontradables } & \multirow{2}{*}{\multicolumn{2}{|c|}{$\begin{array}{l}\text { PPP } \\
\text { index }\end{array}$}} \\
\hline & \multicolumn{2}{|c|}{ Tax rate } & \multicolumn{2}{|c|}{ Demogrant } & \multicolumn{2}{|c|}{ Labor } & \multicolumn{2}{|c|}{ Consump. } & & & & & Ave & $\overline{a g e}$ & $\mathrm{Pr}$ & ice & & \\
\hline & dec. & WIT & dec. & WIT & dec. & WIT & dec. & WIT & dec. & WIT & dec. & WIT & dec. & WIT & dec. & WIT & dec. & WIT \\
\hline 65 & 0.35 & 0.62 & 467 & 3,112 & 0.42 & 0.42 & 0.27 & 0.04 & 0.25 & 0.04 & 1,331 & 3,401 & 0.24 & 0.12 & 1,155 & 6,016 & 0.44 & 0.69 \\
\hline 66 & 0.35 & 0.62 & 464 & 3,112 & 0.42 & 0.42 & 0.27 & 0.04 & 0.25 & 0.04 & 1,315 & 3,400 & 0.24 & 0.12 & 1,147 & 6,019 & 0.44 & 0.69 \\
\hline 67 & 0.54 & 0.62 & 588 & 3,112 & 0.70 & 0.65 & 0.32 & 0.07 & 0.13 & 0.05 & 1,092 & 3,502 & 0.17 & 0.11 & 1,350 & 6,624 & 0.46 & 0.75 \\
\hline 68 & 0.45 & 0.62 & 481 & 3,112 & 0.55 & 0.52 & 0.31 & 0.05 & 0.19 & 0.05 & 1,079 & 3,423 & 0.21 & 0.12 & 1,076 & 6,283 & 0.43 & 0.71 \\
\hline 69 & 0.49 & 0.62 & 500 & 3,112 & .63 & 0.58 & 0.32 & 0.06 & 0.17 & 0.05 & 1,025 & 3,448 & 0.19 & 0.11 & 1,115 & & 0.43 & 0.73 \\
\hline 70 & 0.57 & 0.62 & 483 & 3,112 & .75 & 0.67 & 0.32 & 0.07 & 0.11 & 0.04 & 846 & 3,478 & 0.15 & 0.11 & 1,197 & 6,947 & 0.44 & 0.77 \\
\hline 71 & 0.36 & 0.62 & 345 & 3,112 & 0.44 & 0.43 & 0.28 & 0.04 & 0.24 & 0.04 & 956 & 3,388 & 0.23 & 0.11 & 868 & 6,249 & 0.40 & 0.71 \\
\hline 72 & 0.42 & 0.62 & 309 & 3,112 & 53 & 0.49 & 0.30 & 0.04 & 0.21 & 0.04 & 73 & 3,390 & 0.21 & 0.11 & 734 & 6,514 & 0.38 & 0.73 \\
\hline 73 & 0.63 & 0.62 & 416 & 3,112 & 0.82 & 0.72 & 0.31 & 0.08 & 0.08 & 0.04 & 665 & 3,478 & 0.12 & 0.10 & 1,198 & 7,525 & 0.44 & 0.82 \\
\hline 74 & 0.35 & 0.62 & 258 & 3,112 & .42 & 0.41 & 0.27 & 0.03 & 0.25 & 0.04 & 748 & 3,383 & 0.23 & 0.11 & 692 & 6,414 & 0.38 & 0.72 \\
\hline 75 & 0.46 & 0.62 & 306 & 3,112 & 0.59 & 0.53 & 0.32 & 0.05 & 0.18 & 0.04 & 659 & 3,396 & 0.19 & 0.11 & 719 & 6,678 & 0.38 & 0.74 \\
\hline 76 & 0.41 & 0.62 & 281 & 3,112 & 0.51 & 0.47 & 0.30 & 0.04 & 0.21 & 0.04 & 678 & 3,386 & 0.21 & 0.11 & 682 & 6,541 & 0.38 & 0.73 \\
\hline 77 & .27 & 0.62 & 200 & 3,112 & .33 & 0.3 & 0.24 & 0.03 & 0.29 & 0.04 & 7 & 3,381 & 0.23 & 0.11 & 663 & 6,393 & 0.37 & 0.72 \\
\hline 78 & 0.45 & 0.62 & 281 & 3,112 & .58 & 0.52 & 0.32 & 0.04 & 0.1 & 0.04 & 62 & 3,392 & 0.20 & 0.11 & 666 & 6,707 & 0.37 & 0.75 \\
\hline 79 & 0.51 & 0.62 & 281 & 3,112 & .65 & 0.57 & 0.32 & 0.05 & 0.16 & 0.04 & 557 & 3,398 & 0.17 & 0.10 & 679 & 6,899 & 0.38 & 0.76 \\
\hline 80 & 0.60 & 0.62 & 289 & 3,112 & 0.79 & 0.68 & 0.32 & 0.06 & 0.10 & 0.04 & 481 & 3,428 & 0.12 & 0.10 & 813 & 7,562 & 0.40 & 0.82 \\
\hline 81 & 0.31 & 0.62 & 178 & 3,112 & .37 & 0.37 & 0.25 & 0.03 & 0.27 & 0.04 & 57 & 3,381 & 0.22 & 0.11 & 540 & 6,596 & 0.35 & 0.74 \\
\hline 82 & 0.70 & 0.62 & 328 & 3,112 & 90 & 0.78 & 0.27 & 0.08 & 0. & 0.0 & & & 0.08 & 0 & 1,237 & 8,712 & 0.44 & 0.91 \\
\hline 83 & 0.72 & 0.62 & 322 & 3,112 & 91 & 0.79 & 0.25 & 0.08 & 0. & 0.0 & 4 & 70 & 0.07 & 0.08 & 1,323 & 8,992 & 0.45 & 0.93 \\
\hline 84 & 0.50 & 0.62 & 216 & 3,112 & 64 & 0.56 & 0.32 & 0.05 & 0.16 & 0.04 & 434 & 3,390 & 0.17 & 0.10 & 536 & 7,091 & 0.35 & 0.78 \\
\hline 85 & 0.51 & 0.62 & 218 & 3,112 & .66 & 0.58 & 0.32 & 0.05 & 0.15 & 0.04 & 431 & 3,391 & 0.17 & 0.10 & 545 & 7,133 & 0.35 & 0.78 \\
\hline 86 & 0.34 & 0.62 & 159 & 3,112 & .40 & 0.40 & 0.27 & 0.03 & 026 & 0.04 & 17 & 3,381 & 0.22 & 0.11 & 461 & 6,764 & 0.33 & 0.75 \\
\hline 87 & 0.39 & 0.62 & 168 & 3,112 & 47 & 0.45 & 0.29 & 0.04 & 0.23 & 0. & & 31 & 0.21 & 0. & 45 & 6 , & 0.33 & 0.76 \\
\hline 88 & 0.47 & 0.62 & 182 & 3,112 & .60 & 0.5 & 0.32 & 0.04 & 0.18 & 0.0 & 38 & 84 & 0.18 & 0.1 & 56 & 7,100 & 0.33 & 0.78 \\
\hline 89 & 0.62 & 0.62 & 223 & 3,112 & .82 & 0.70 & 0.31 & 0.06 & 0.09 & 0.04 & 358 & 3,414 & 0.11 & 0.09 & 685 & 7,974 & 0.38 & 0.86 \\
\hline 90 & 0.41 & 0.62 & 144 & 3,112 & .50 & 0.47 & 0.30 & 0.04 & 0.22 & 0.0 & 3 & 31 & 0.20 & 0.10 & 380 & 7,061 & 0.32 & 0.78 \\
\hline 91 & 9 & 0.6 & 15 & & & & & & & & & & 0.17 & & 03 & & 0.32 & 0.80 \\
\hline 92 & 0.45 & 0.62 & 146 & 3,112 & 57 & 0.51 & 0.31 & 0.04 & 0. & 0. & 3 & 81 & 0.18 & 0.10 & 376 & 7,203 & 0.31 & 0.79 \\
\hline 93 & 0.43 & 0.62 & 140 & 3,112 & .52 & 0.48 & 0.30 & 0.04 & 0.21 & 0.0 & 33 & 3,381 & 0.19 & 0.10 & 368 & 7,132 & 0.31 & 0.78 \\
\hline 94 & 0.29 & 0.62 & 108 & 3,112 & .34 & 0.35 & 0.24 & 0.03 & 0.28 & 0.0 & 37 & 3,381 & 0.21 & 0.10 & 367 & 6,938 & 0.31 & 0.77 \\
\hline 95 & 0.55 & 0.62 & 165 & 3,112 & 72 & 0.62 & 0.32 & 0.05 & 0.13 & 0. & ? & 9 & 0.14 & 0 & 50 & 04 & 0.33 & 0.83 \\
\hline 96 & 9 & 0. & 6 & 3,112 & 3 & 0. & 0. & 0.04 & & 0 & & & 0.17 & & 77 & & 0.31 & 0.80 \\
\hline 97 & 0.41 & 0.6 & 130 & 3,112 & 51 & 0. & 0.30 & 0.04 & 0 & 0. & 3 & 81 & 0.19 & 0 & 46 & 7,173 & 0.31 & 0.79 \\
\hline 98 & 0.59 & 0.62 & 164 & 3,112 & .77 & 0.65 & 0.32 & 0.05 & 0.1 & 0.0 & 28 & 94 & 0.12 & 0.0 & 478 & 7,878 & 0.34 & 0.85 \\
\hline 99 & 0.33 & 0.62 & 105 & 3,112 & 39 & 0.39 & 0.27 & 0.03 & 0.26 & 0.0 & 32 & 3,381 & 0.21 & 0.10 & 325 & 7,086 & 0.30 & 0.78 \\
\hline 100 & 0.49 & 0.62 & 133 & 3,112 & 52 & 0.55 & 0.32 & 0.04 & 0 & 0. & & & 0.17 & 0 & 47 & 7,443 & 0.31 & 0.81 \\
\hline 10 & 0.62 & 0.6 & 163 & 3,112 & 1 & 0.6 & 0. & 0.06 & & & & & 0.11 & & 15 & & 0.35 & 0.87 \\
\hline 102 & 0.63 & 0. & 161 & 3,1 & 2 & 0. & 0. & 0.06 & 0 & 0 & & & 0.10 & & 19 & & 0.35 & 0.88 \\
\hline 103 & 0.35 & 0.62 & 101 & 3,112 & 42 & 0.41 & 0.27 & 0.03 & 0.25 & 0.0 & 28 & 3,381 & 0.20 & 0.10 & 299 & 7,191 & 0.29 & 0.79 \\
\hline 104 & 0.78 & 0.62 & 207 & 3,112 & 96 & 0.85 & 0.21 & 0.08 & 0.03 & 0.0 & 26 & 3,444 & 0.04 & 0.06 & 1,322 & 12,118 & 0.45 & 1.15 \\
\hline 105 & 0.38 & 0.6 & 98 & 3,112 & 46 & 0.44 & 0.29 & 0.04 & 0.23 & 0. & 2 & & 0.20 & 0.10 & 281 & 7,298 & 0.29 & 0.80 \\
\hline 106 & 0.50 & 0. & 110 & & & 0. & 0. & 0. & & & & & 0.16 & & 98 & & 0.29 & 0.83 \\
\hline 107 & 0.57 & 0.62 & 117 & 3,112 & .74 & 0.6 & 0.3 & 0.05 & 0 & 0. & 2( & 35 & 0.13 & 0 & 343 & 8,027 & 0.30 & 0.86 \\
\hline 108 & 0.47 & 0.62 & 98 & 3,112 & 60 & 0.54 & 0.32 & 0.04 & 0.18 & 0.0 & 207 & 3,381 & 0.17 & $0.0 s$ & 264 & 7,658 & 0.28 & 0.83 \\
\hline 109 & 0.63 & 0.62 & 124 & 3,112 & .82 & 0.68 & 0.30 & 0.06 & 0.08 & 0. & 197 & 3,392 & 0.10 & 0.08 & 414 & 8,485 & 0.32 & 0.90 \\
\hline 110 & 0.60 & 0.62 & 118 & 3,112 & .78 & 0.66 & 0.31 & 0.05 & 0.10 & 0.04 & $1 s$ & & 0.11 & 0.09 & 368 & 8,242 & 0.31 & 0.88 \\
\hline 111 & 0.49 & 0.6 & 9 & 3,112 & 0.63 & 0.5 & 0.32 & 0.04 & & 0. & $1 s$ & & 0.16 & & 61 & & 0.28 & 0.84 \\
\hline 112 & 0.45 & 0.6 & 86 & 3,112 & & 0. & 0.31 & 0.04 & & 0. & 19 & & 0.17 & 0.09 & 236 & 7,683 & 0.27 & 0.83 \\
\hline 11 & 0.80 & 0.62 & 139 & 3,112 & 0.96 & 0.85 & 0.19 & 0.08 & 0.02 & 0.0 & 17 & 3,420 & 0.04 & 0.05 & 1,027 & 13,287 & 0.42 & 1.26 \\
\hline 114 & 0.63 & 0.62 & 98 & 3,112 & .82 & 0.68 & 0.30 & 0.06 & 0.08 & $0 . C$ & 156 & 3,386 & 0.10 & 0.08 & 337 & 8,707 & 0.30 & 0.92 \\
\hline 115 & 0.70 & 0.62 & 96 & 3,112 & 0.90 & 0.76 & 0.27 & 0.06 & 0.05 & $0 . C$ & 138 & 3,396 & 0.07 & 0.07 & 420 & 10,026 & 0.32 & 1.03 \\
\hline 11 & 0.81 & 0.62 & 98 & 3,112 & 0.97 & 0.86 & 0.19 & 0.08 & 0.02 & 0.0 & 121 & 3,406 & 0.03 & 0.0 & 843 & 15,187 & 0.40 & 1.41 \\
\hline 11 & 0.42 & 0.6 & 45 & 3,112 & 0.51 & 0.48 & 0.30 & 0.04 & 0.21 & 0.0 & 108 & 3,381 & 0.17 & 0.0 & 135 & 8,155 & 0.22 & 0.87 \\
\hline 118 & 0.50 & 0.62 & 42 & 3,112 & 0.64 & 0.56 & 0.32 & 0.05 & 0.16 & 0.04 & 85 & 3,381 & 0.14 & 0.08 & 127 & 8,589 & 0.22 & 0.91 \\
\hline
\end{tabular}


Table A-3b: Comparison of the Optimal Decentralized and World Income Taxes, Further Details.

\begin{tabular}{|c|c|c|c|c|c|c|c|c|c|c|c|c|c|c|c|c|}
\hline & \multirow{2}{*}{\multicolumn{2}{|c|}{$\begin{array}{c}\text { Average } \\
\text { Labor Income }\end{array}$}} & \multirow{2}{*}{\multicolumn{2}{|c|}{$\begin{array}{c}\text { GNP } \\
\text { Consumption }\end{array}$}} & \multirow{2}{*}{\multicolumn{2}{|c|}{ Revenue }} & \multicolumn{6}{|c|}{ Consumption Percentiles } & \multicolumn{4}{|c|}{ U.S. Welfare } \\
\hline & & & & & & & $5 \%$ & & $50 \%$ & & & & era & elfa & & \\
\hline & dec & WIT & dec. & WIT & dec. & WIT & & & T & & $\mathrm{dec}$. & & & WIT & dec & $\overline{\text { WIT }}$ \\
\hline Vld. & 5,027 & 5,016 & $2 \%$ & $15 \%$ & 0.0 & 0.0 & 566 & 4,962 & 1,599 & 6,198 & 8,784 & 14,043 & 564,213 & $-4,384,246$ & 0.1591 & 0.3795 \\
\hline 1 & 3249 & 9451 & $0 \%$ & $0 \%$ & م & 653 & $\overline{464}$ & 34 & 28 & 921 & y? & & 178 & & & \\
\hline 2 & 163 &, 293 & $0 \%$ & $0 \%$ & & 504.5 & 24,788 & 9,527 & 31,076 & & ,748 & 40,416 & $-2,502,612$ & $-3,379,862$ & 5370 & 4922 \\
\hline 3 & 36,341 & 35,243 & $0 \%$ & $0 \%$ & 0. & 751.5 & 24,674 & 8 & 31,402 & & 4,349 & 30,025 & $-2,602,954$ & $-3,454,813$ & 1.4493 & .4359 \\
\hline 4 & 35,523 & 34,499 & $0 \%$ & $0 \%$ & 0.0 & $18,289.9$ & 24,399 & 9,792 & 30,940 & 14,491 & 61,895 & 29,013 & $-2,616,832$ & $-3,467,047$ & 1.4200 & .4207 \\
\hline 5 & 35,256 & 34,245 & $0 \%$ & $0 \%$ & 0.0 & $18,132.2$ & 24,293 & 9,771 & 30,775 & 14,430 & 61,200 & 28,718 & $-2,621,713$ & $-3,471,425$ & 1.4097 & .4140 \\
\hline 6 & 29,058 & 31,504 & $0 \%$ & $0 \%$ & 0.0 & 432.0 & 17,373 & 6,835 & 20,198 & 10,8 & 683 & 37,657 & $-2,698,305$ & $-3,608,738$ & 1.0000 & .0000 \\
\hline 7 & 28,616 & 0,459 & $0 \%$ & $0 \%$ & & 83.9 & 17,349 & 97 & & & & 082 & $-2,720,756$ & $-3,612,741$ & 0.9909 & .0136 \\
\hline 8 & 29,358 & 6,938 & $0 \%$ & $0 \%$ & 0 & 599.3 & 20,571 & 537 & 26,016 & & 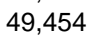 & 22,713 & $-2,788,604$ & $-3,624,308$ & 1.1158 & 1531 \\
\hline 9 & 26,758 & 25,842 & $0 \%$ & $0 \%$ & 0.0 & $12,919.9$ & 17,342 & 7,335 & 22,015 & 10,955 & 51,181 & 25,508 & $-2,827,967$ & $-3,666,763$ & 0.9492 & .0162 \\
\hline 10 & 27,581 & 25,707 & $0 \%$ & $0 \%$ & 0.0 & $12,835.6$ & 18,943 & 8,004 & 24,047 & 11,520 & 48,257 & 22,878 & $-2,824,413$ & $-3,656,582$ & 1.0214 & .0820 \\
\hline 11 & 27,012 & 25,077 & $0 \%$ & $0 \%$ & 0.0 & 45.3 & 18,553 & 7,875 & 23,551 & ,306 & 7,262 & 22,430 & $-2,842,209$ & $-3,6$ & .9941 & .0586 \\
\hline 12 & 1,995 & 4,516 & $0 \%$ & $0 \%$ & & 97.3 & 856 & 6,8 & & & & 78 & $-2,870,084$ & $-3,7$ & 8575 & 9374 \\
\hline 13 & 26,232 & 24,153 & $0 \%$ & $0 \%$ & 0.0 & 71.9 & 17,862 & 7,6 & 22,720 &, 924 & , , & 21,942 & $-2,870,106$ & $-3,695,599$ & 0.9509 & 0178 \\
\hline 14 & 21,669 & 23,026 & $0 \%$ & $0 \%$ & 0.0 & $11,172.5$ & 12,695 & 5,413 & 14,568 & 7,875 & & 30,763 & $-2,9$ & $-3,812,202$ & 0.6703 & .7298 \\
\hline 15 & 24,125 & 23,503 & $0 \%$ & $0 \%$ & 0 & 468.5 & 15,295 & 6,641 & 19,218 & 9,891 & 48,044 & 24,877 & -2, & $-3,7$ & 0.8188 & .9053 \\
\hline 16 & 22,433 & 22,404 & $0^{\circ}$ & 0 & ) & 87.1 & 13,827 & 2 & 935 & 9,061 & ,212 & 748 & & $-3,7$ & .7312 & .8247 \\
\hline 17 & 20,114 & 19,341 & $0 \%$ & $0 \%$ & 0.0 & 886.8 & 12,502 & 5,747 & 15,464 & 8,3 & , 590 & 22,403 & $-3,049,718$ & $-3,846,992$ & 0.6374 & .7511 \\
\hline 18 & 21,344 & 19,171 & $0 \%$ & $0 \%$ & 0.0 & $8,781.0$ & 14,287 & 6,4 & 18,188 & 0. & , & 19,090 & $-3,0$ & $-3,830,559$ & 0.7210 & 8249 \\
\hline 9 & 19,975 & 18,570 & $0 \%$ & $0 \%$ & 0.0 & $8,408.1$ & 12,816 & & 16,165 & & & & & $-3,8$ & 0.6459 & .7638 \\
\hline 20 & 189 & 18,277 & $0 \%$ & $0 \%$ & 0.0 & $8,226.4$ & 830 & & & & & & & -3, & 5953 & .7139 \\
\hline 21 & 417 & 16,283 & $0^{\circ}$ & 0 & 0.0 & 989.7 & 10,812 & & & & & & & & 5284 & .6618 \\
\hline 22 & ,368 & 12,256 & $0 \%$ & $0 \%$ & 0.0 & $4,491.4$ & 9,137 & 828 & 11,475 & 6 & & 256 & $-3,3$ & -4, & 4183 & .5705 \\
\hline 23 & 12,722 & 11,973 & $0 \%$ & $0 \%$ & 0.0 & $4,315.9$ & 7,539 & 4,228 & 8,612 & 6 & & 335 &, 870 & 5,889 & 3387 & .4979 \\
\hline 4 & 12,089 & 9612 & $0 \%$ & $0 \%$ & 0.0 & $2,870.2$ & 663 & & & & & & & & 31 & .4973 \\
\hline 25 & 589 & 8,33 & $\%$ & $0 \%$ & 0.0 & 061.5 & 6,566 & & & & & & & & 61 & .4522 \\
\hline 26 & 687 & 7,4 & $0 \%$ & 0 & 0.0 & $1,498.7$ & & & & & & & & & 45 & 552 \\
\hline 27 & 841 & 6,238 & $0 \%$ & & 0. & 758.2 & 4,605 & & 5,276 & 3 & 18,292 & & & -4 & 1788 & .3776 \\
\hline 0 & 540 & 3,619 & $0 \%$ & $0 \%$ & 0.0 & -866.3 & 3,289 & 8 & 3,756 & & 12,715 & & 514 & 4,366 & .1149 & 3294 \\
\hline & 581 & 2209 & $0 \%$ & $0 \%$ & 0 & $-1,741.2$ & 812 & & & & & & & & 272 & .3110 \\
\hline 30 & & 3,1 & & $6^{6}$ & 0 & & 2,308 & & & & 10 & & & & & .3044 \\
\hline 31 & 41 & 2,078 & $0 \%$ & $0 \%$ & 0. & 2.3 & 3,126 & & $3, \AA$ & & 9,393 & 5,715 & & & & .3047 \\
\hline 32 & 506 & 2,272 & & $1 \%$ & 0.0 & 1.9 & 2,743 & 32 & & & 728 & & & & & 3054 \\
\hline 33 & 712 & 3,063 & 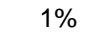 & $10 \%$ & & & 20 & & & & 9,078 & & & & & \\
\hline & & & & & & & & & & & & & & & & 016 \\
\hline & 14 & , 2 & & & & & & & & & & & & & & .3029 \\
\hline 36 & 41 & 64 & & 0 & & & 2,566 & 1 & 3,2 & & 77 & 5 & & & & 2933 \\
\hline 37 & 3,275 & 2,031 & & 5 & & & 1,900 & 12 & 2,205 & & & & & & & 2928 \\
\hline 3 & & & & & & & & & & & & & & & & \\
\hline & & & & & & & & & & & & & & & & 14 \\
\hline & & & & & & & & & & & & & & & & 2871 \\
\hline 41 & 62 & 1 & & 6 & & 83.0 & 4 & 2 & & & 55 & 89 & & -4 & 19 & .2893 \\
\hline 42 & & 3,44 & & & & 973.9 & & & & & & & & & & 2094 \\
\hline 43 & & & & & & & & & & & & & & & & 34 \\
\hline & & & & & & & & & & & & & & & & 2410 \\
\hline & & & & & & & & & & & & & & & & 2770 \\
\hline 4 & 34 & & & & & & & & & & & 70 & & & 81 & .2818 \\
\hline 47 & 187 & ,37 & & & & & & & & & & & & & & 2811 \\
\hline $4 \varepsilon$ & & & & & & & & & & & & & & & & 753 \\
\hline & & 1,2 & & & & & & & & & & & & & & 2796 \\
\hline & & & & & & & & & & & & & & & & .2745 \\
\hline 5 & & 17 & & & & 4.3 & & 2 & & & & & & & & .2771 \\
\hline 5 & & & & & & & & & & & & & & & & .2769 \\
\hline 53 & & & & & & & & & & & & & & & & .2684 \\
\hline & & & & & & & & & & & & & & & & \\
\hline & & & & & & & & & & & & & & & & .2739 \\
\hline 5 & & & & & & -2 & 013 & & & & & & & & 230 & .2720 \\
\hline 57 & 1,710 & 1,026 & & $13 \%$ & 0 & 75.2 & 988 & & & 3, & & & 338 & & 243 & .2726 \\
\hline 58 & & & & & & & 95 & & & & & & & & & .2725 \\
\hline & & & & & & & 83 & & 1 , & & & & & & & 995 \\
\hline & & & & & & & & & 9 & & & & & & & \\
\hline 6 & & 1,0 & & & & -2 & 760 & & 91 & & 3,262 & & 45 & 89,671 & .0174 & .2684 \\
\hline 62 & & & $0 \%$ & $16 \%$ & 0. & & 192 & & $y_{i}$ & & & & & & 0.0182 & .2694 \\
\hline 63 & 1,624 & 71 & 47 & $2^{\circ}$ & 0. & $-2,667.1$ & 1,078 & 3,164 & 1,369 & 3,378 & 3,007 & & & 03 & 51 & 0.2693 \\
\hline 64 & 1,310 & 921 & $0 \%$ & $17 \%$ & 0.0 & $-2,540.3$ & 754 & 3,112 & 884 & 3,373 & 3,223 & 3,913 & $-6,753,051$ & $-4,487,077$ & 0.0171 & 0.268 \\
\hline
\end{tabular}


Table A-3b: Comparison of the Optimal Decentralized and World Income Taxes, Further Details.

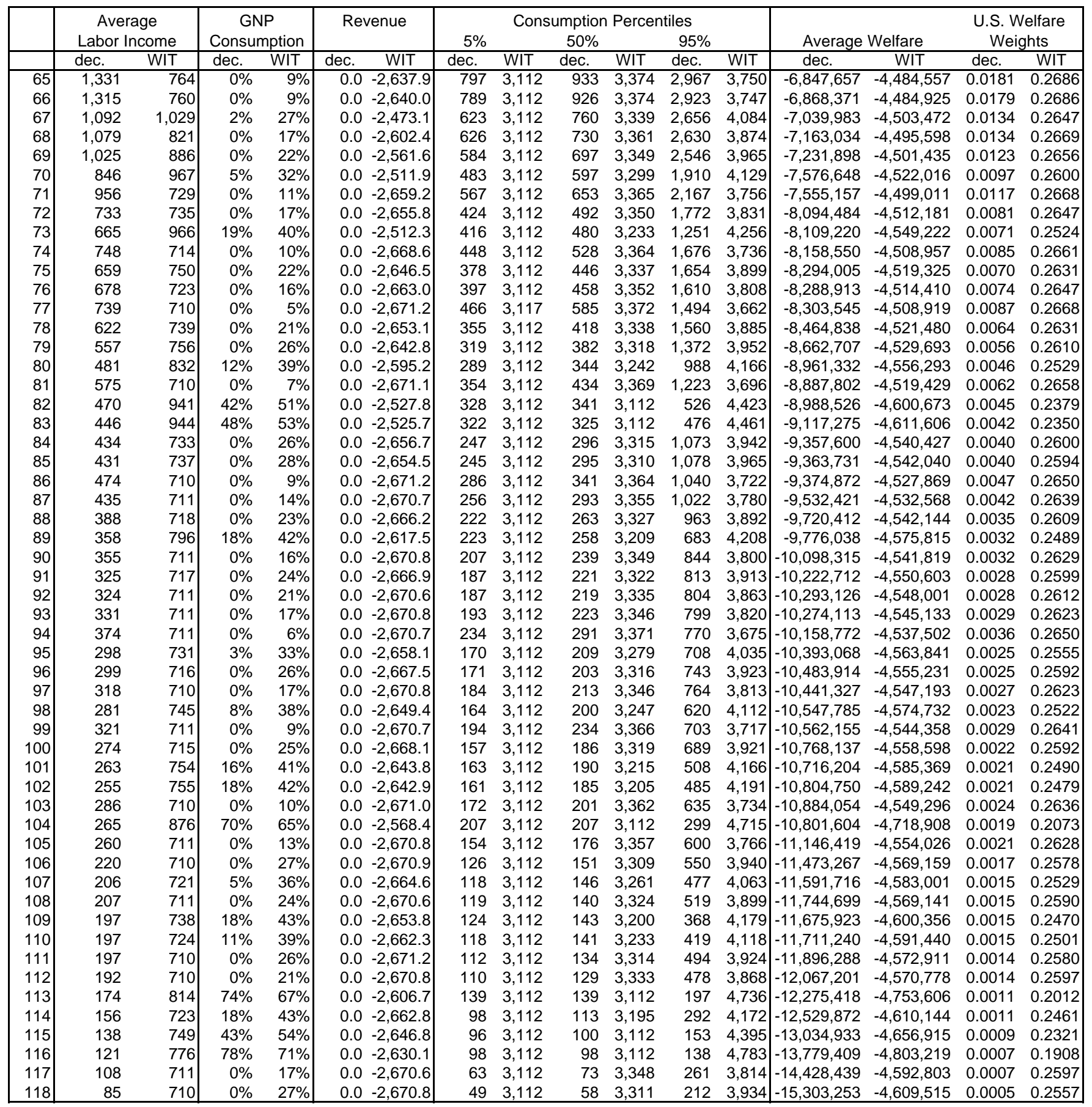


Table A-4 - Sensitivity Analysis

\begin{tabular}{|c|c|c|c|c|c|c|c|c|c|c|c|c|c|c|c|c|c|c|}
\hline \multirow{3}{*}{ Country } & \multirow{2}{*}{\multicolumn{2}{|c|}{$\begin{array}{c}\text { Average } \\
\text { Labor Supply }\end{array}$}} & \multirow{2}{*}{\multicolumn{2}{|c|}{ Demogrant }} & \multicolumn{4}{|c|}{ Gini Coefficients } & \multirow{2}{*}{\multicolumn{2}{|c|}{$\begin{array}{c}\text { Average } \\
\text { Labor Supply }\end{array}$}} & \multirow{2}{*}{\multicolumn{2}{|c|}{ Unemployment }} & \multirow{2}{*}{\multicolumn{2}{|c|}{$\begin{array}{c}\text { Average } \\
\text { Consumption }\end{array}$}} & \multirow{2}{*}{\multicolumn{2}{|c|}{$\begin{array}{c}\text { Average } \\
\text { Labor Income }\end{array}$}} & \multirow{2}{*}{\multicolumn{2}{|c|}{ Revenue }} \\
\hline & & & & & \multicolumn{2}{|c|}{ Labor Income } & \multicolumn{2}{|c|}{ Consumption } & & & & & & & & & & \\
\hline & dec. & WIT & dec. & WIT & dec. & WIT & dec. & WIT & dec. & WIT & \multicolumn{2}{|c|}{$\begin{array}{ll}\text { dec. } & \text { WIT } \\
\end{array}$} & \multirow{2}{*}{ dec. } & \multirow[t]{2}{*}{ WIT } & \multirow[t]{2}{*}{ dec. } & \multirow{2}{*}{ WIT } & \multicolumn{2}{|c|}{$\begin{array}{ll}\text { dec. } & \text { WIT } \\
\end{array}$} \\
\hline \multicolumn{15}{|l|}{$\mathrm{v}=0.5$} & & & & \\
\hline World & 0.36 & 0.60 & 1,329 & 3,061 & 0.75 & 0.79 & 0.69 & 0.26 & 0.23 & 0.09 & $1 \%$ & $13 \%$ & 5,266 & 5,067 & 5,266 & 5,067 & 0.0 & 0.0 \\
\hline 6 United State & 0.30 & 0.60 & 9,244 & 3,061 & 0.41 & 0.44 & 0.29 & 0.35 & 0.27 & 0.30 & $0 \%$ & $0 \%$ & 30,569 & 15,655 & 30,569 & 31,811 & 0.0 & $16,155.7$ \\
\hline 36 Poland & 0.21 & 0.60 & 913 & 3,061 & 0.31 & 0.44 & 0.24 & 0.08 & 0.31 & 0.08 & $0 \%$ & $0 \%$ & 4,275 & 3,749 & 4,275 & 1,739 & 0.0 & $-2,010.4$ \\
\hline 88 India & 0.43 & 0.60 & 172 & 3,061 & 0.58 & 0.52 & 0.33 & 0.04 & 0.20 & 0.04 & $0 \%$ & $21 \%$ & 404 & 3,342 & 404 & 709 & 0.0 & $-2,632.5$ \\
\hline \multicolumn{19}{|l|}{$\mathrm{V}=\mathbf{2 . 0}$} \\
\hline World & 0.41 & 0.62 & 1,539 & 3,112 & 0.75 & 0.79 & 0.69 & 0.25 & 0.21 & 0.09 & $2 \%$ & $15 \%$ & 5,027 & 5,016 & 5,027 & 5,016 & 0.0 & 0.0 \\
\hline 6 United State & 0.36 & 0.62 & 10,373 & 3,112 & 0.43 & 0.44 & 0.28 & 0.35 & 0.25 & 0.29 & $0 \%$ & $0 \%$ & 29,058 & 15,072 & 29,058 & 31,504 & 0.0 & $16,432.0$ \\
\hline 36 Poland & 0.28 & 0.62 & 1,127 & 3,112 & 0.32 & 0.45 & 0.23 & 0.08 & 0.28 & 0.08 & $0 \%$ & $0 \%$ & 4,041 & 3,737 & 4,041 & 1,646 & 0.0 & $-2,090.2$ \\
\hline 88 India & 0.47 & 0.62 & 182 & 3,112 & 0.60 & 0.53 & 0.32 & 0.04 & 0.18 & 0.04 & $0 \%$ & $23 \%$ & 388 & 3,384 & 388 & 718 & 0.0 & $-2,666.2$ \\
\hline \multicolumn{19}{|l|}{$\mathrm{v}=5.0$} \\
\hline World & 0.45 & 0.64 & 1,722 & 3,162 & 0.76 & 0.79 & 0.69 & 0.24 & 0.19 & 0.08 & $2 \%$ & $16 \%$ & 4,778 & 4,955 & 4,778 & 4,955 & 0.0 & 0.0 \\
\hline 6 United States & 0.41 & 0.64 & 11,252 & 3,162 & 0.45 & 0.45 & 0.26 & 0.35 & 0.23 & 0.29 & $0 \%$ & $0 \%$ & 27,598 & 14,433 & 27,598 & 31,147 & 0.0 & $16,713.8$ \\
\hline 36 Poland & 0.33 & 0.64 & 1,280 & 3,162 & 0.34 & 0.45 & 0.23 & 0.07 & 0.26 & 0.07 & $0 \%$ & $1 \%$ & 3,837 & 3,722 & 3,837 & 1,548 & 0.0 & $-2,174.2$ \\
\hline 88 India & 0.51 & 0.64 & 189 & 3,162 & 0.61 & 0.55 & 0.30 & 0.04 & 0.16 & 0.04 & $0 \%$ & $25 \%$ & 374 & 3,425 & 374 & 725 & 0.0 & $-2,699.5$ \\
\hline
\end{tabular}

\begin{tabular}{|c|c|c|c|c|c|c|c|c|c|c|c|c|c|c|c|c|}
\hline & \multicolumn{4}{|c|}{ Non-Tradables } & \multirow{2}{*}{\multicolumn{2}{|c|}{ PPP }} & \multicolumn{6}{|c|}{ Consumption Percentiles } & & \multirow{2}{*}{\multicolumn{2}{|c|}{$\begin{array}{l}\text { U.S. Welfare } \\
\text { Weights }\end{array}$}} \\
\hline & \multicolumn{2}{|c|}{ Average } & \multicolumn{2}{|c|}{ Price } & & & \multicolumn{2}{|c|}{$5 \%$} & \multicolumn{2}{|c|}{$50 \%$} & \multicolumn{2}{|c|}{$95 \%$} & & & & \\
\hline & dec. & WIT & dec. & WIT & dec. & WIT & dec. & WIT & dec. & WIT & dec. & WIT & \multicolumn{2}{|c|}{ Average Welfare } & \\
\hline \multicolumn{17}{|l|}{$\mathrm{v}=0.5$} \\
\hline World & .24 & 0.13 & 3,290 & 7,412 & & & 574 & 5,046 & 1,677 & 6,292 & 29,970 & 14,595 & 0.0007842 & 0.0009 & 0.1982 & 0.4266 \\
\hline 6 United States & 0.38 & 0.26 & 17,033 & 12,504 & 1.00 & 1.00 & 17,691 & 7,077 & 21,167 & 11,203 & 70,509 & 39,202 & 0.0012300 & 0.0010700 & 1.0000 & 1.0000 \\
\hline 36 Poland & 0.31 & 0.15 & 2,941 & 5,351 & 0.57 & 0.68 & 2,641 & 3,243 & 3,390 & 3,513 & 8,714 & 5,349 & 0.0009000 & 0.0009500 & 0.2018 & 0.3506 \\
\hline 88 India & 0.20 & 0.10 & 434 & 6,744 & 0.33 & 0.76 & 223 & 3,061 & 265 & 3,288 & 1,031 & 3,848 & 0.0006500 & 0.0009400 & 0.0235 & 0.3201 \\
\hline \multicolumn{17}{|l|}{$\mathrm{v}=2.0$} \\
\hline World & 0.22 & 0.13 & 3,371 & 7,687 & & & 566 & 4,962 & 1,599 & 6,198 & 28,784 & 14,043 & $-75 t$ & 246 & 0.1591 & 0.3795 \\
\hline 6 United States & 0.35 & 0.25 & 17,525 & 12,467 & 1.00 & 1.00 & 17,373 & 6,835 & 20,198 & 10,808 & 65,683 & 37,657 & -2698305 & -3608738 & 1.0000 & 1.0000 \\
\hline 36 Poland & 0.28 & 0.14 & 2,992 & 5,578 & 0.57 & 0.69 & 2,566 & 3,261 & 3,216 & 3,531 & 8,097 & 5,195 & -4961715 & -4422498 & 0.0802 & 0.2933 \\
\hline 88 India & 0.18 & 0.10 & 456 & 7,100 & 0.33 & 0.78 & 222 & 3,112 & 263 & 3,327 & 963 & 3,892 & -9720412 & -4542144 & 0.0035 & 0.2609 \\
\hline \multicolumn{17}{|l|}{$v=5.0$} \\
\hline World & 0.20 & 0.12 & 3,458 & 006 & & & 561 & 4,864 & 1,527 & 6,081 & 27,408 & 13,433 & 52943 & +25 & 0.1385 & 0.3273 \\
\hline 6 United States & 0.32 & 0.24 & 18,063 & 12,428 & 1.00 & 1.00 & 17,014 & 6,570 & 19,233 & 10,375 & 61,132 & 35,966 & $-1.41054 \mathrm{E}+25$ & $-5.04691 E+25$ & 1.0000 & 1.0000 \\
\hline 36 Poland & 0.27 & 0.13 & 3,042 & 5,846 & 0.57 & 0.70 & 2,493 & 3,277 & 3,060 & 3,548 & 7,572 & 5,024 & $-1.60721 E+26$ & $-9.56694 \mathrm{E}+25$ & 0.0129 & 0.2245 \\
\hline 88 India & 0.17 & 0.10 & 477 & 7,509 & 0.34 & 0.80 & 221 & 3,162 & 261 & 3,363 & 905 & 3,933 & $-2.35890 \mathrm{E}+27$ & $-1.05833 E+26$ & 0.0001 & 0.1883 \\
\hline
\end{tabular}


Figure 1: Optimal Tax Functions - PPP model

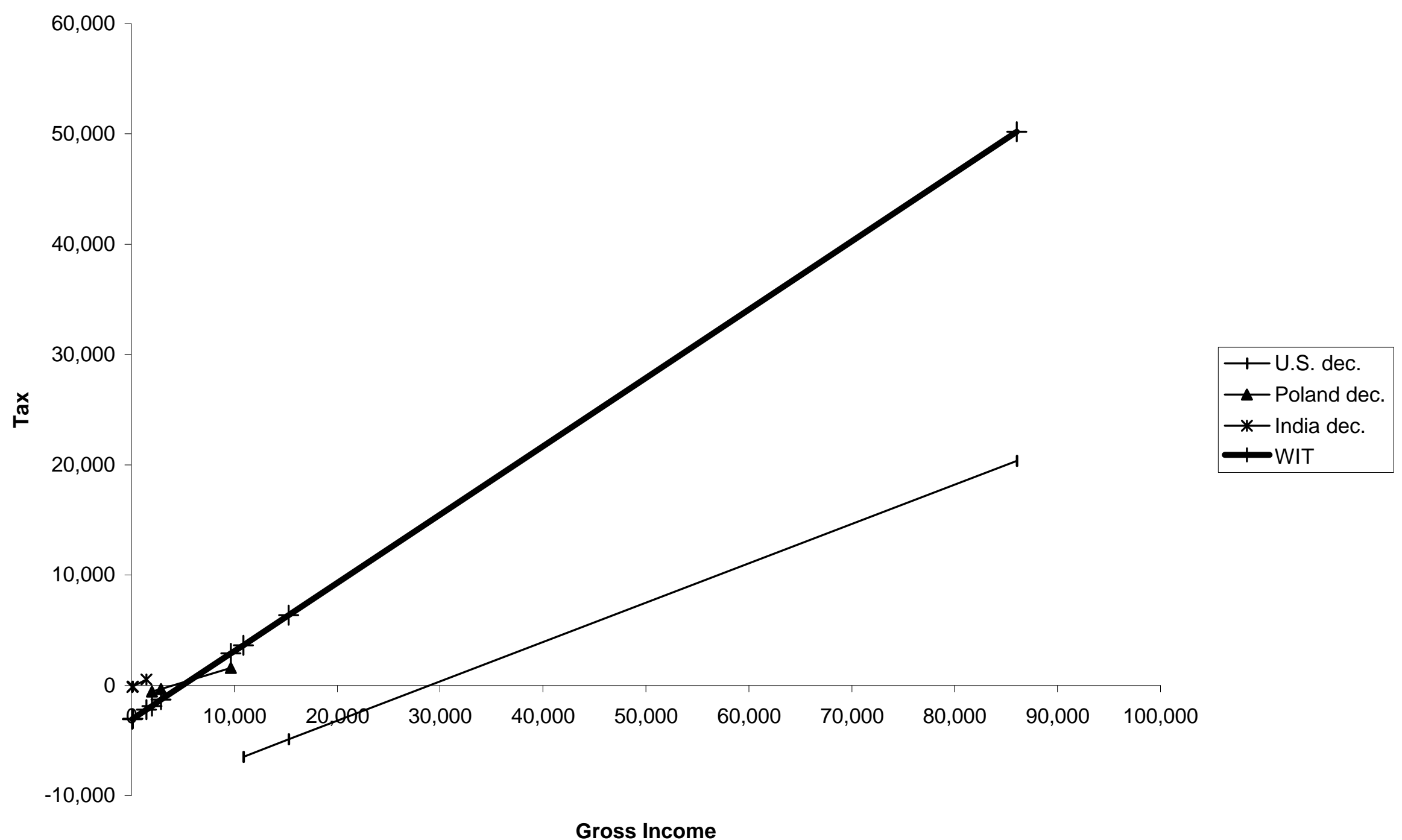


Figure 2: Actual vs. Calibrated PPP

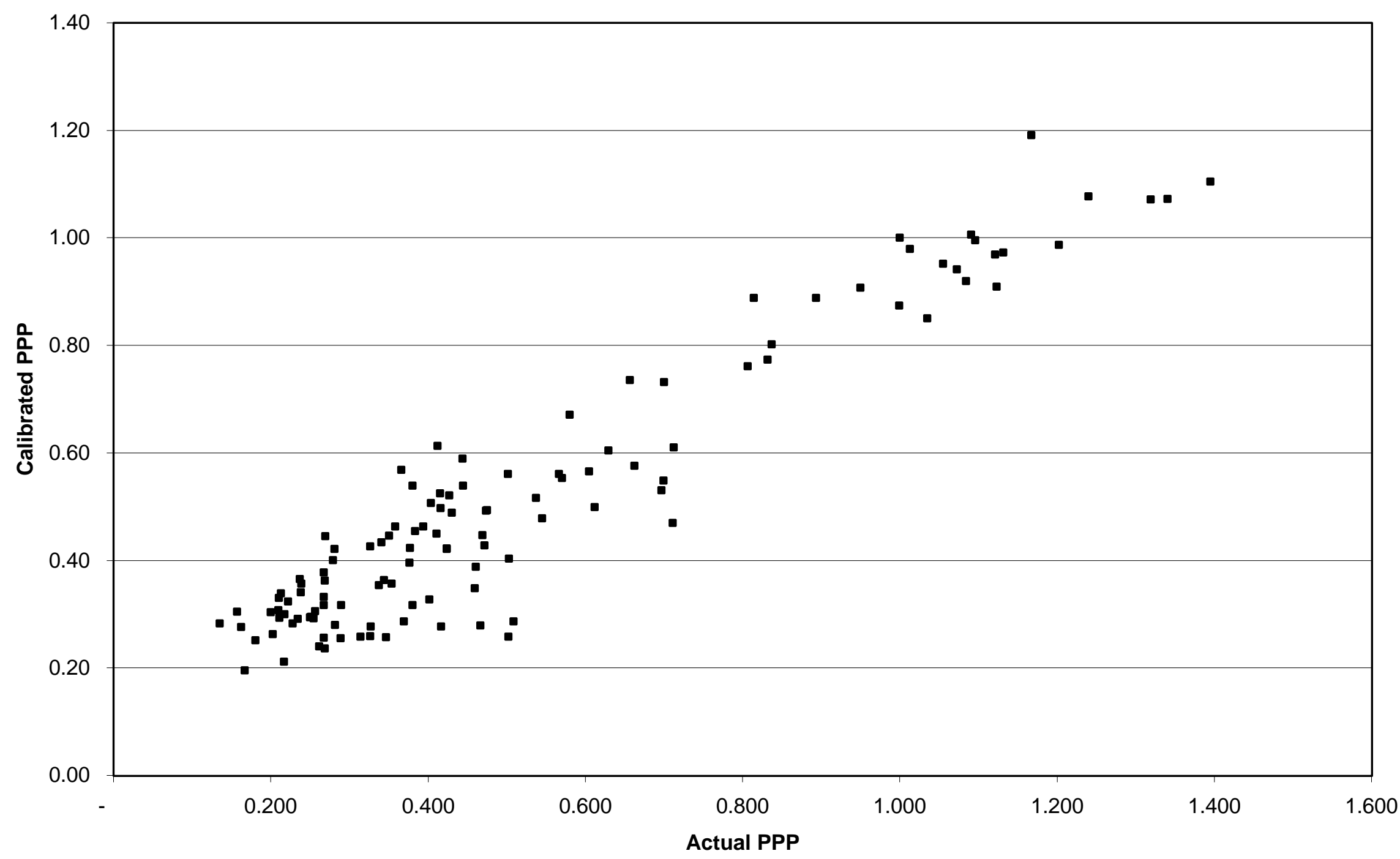


Figure 3: Income vs. PPP

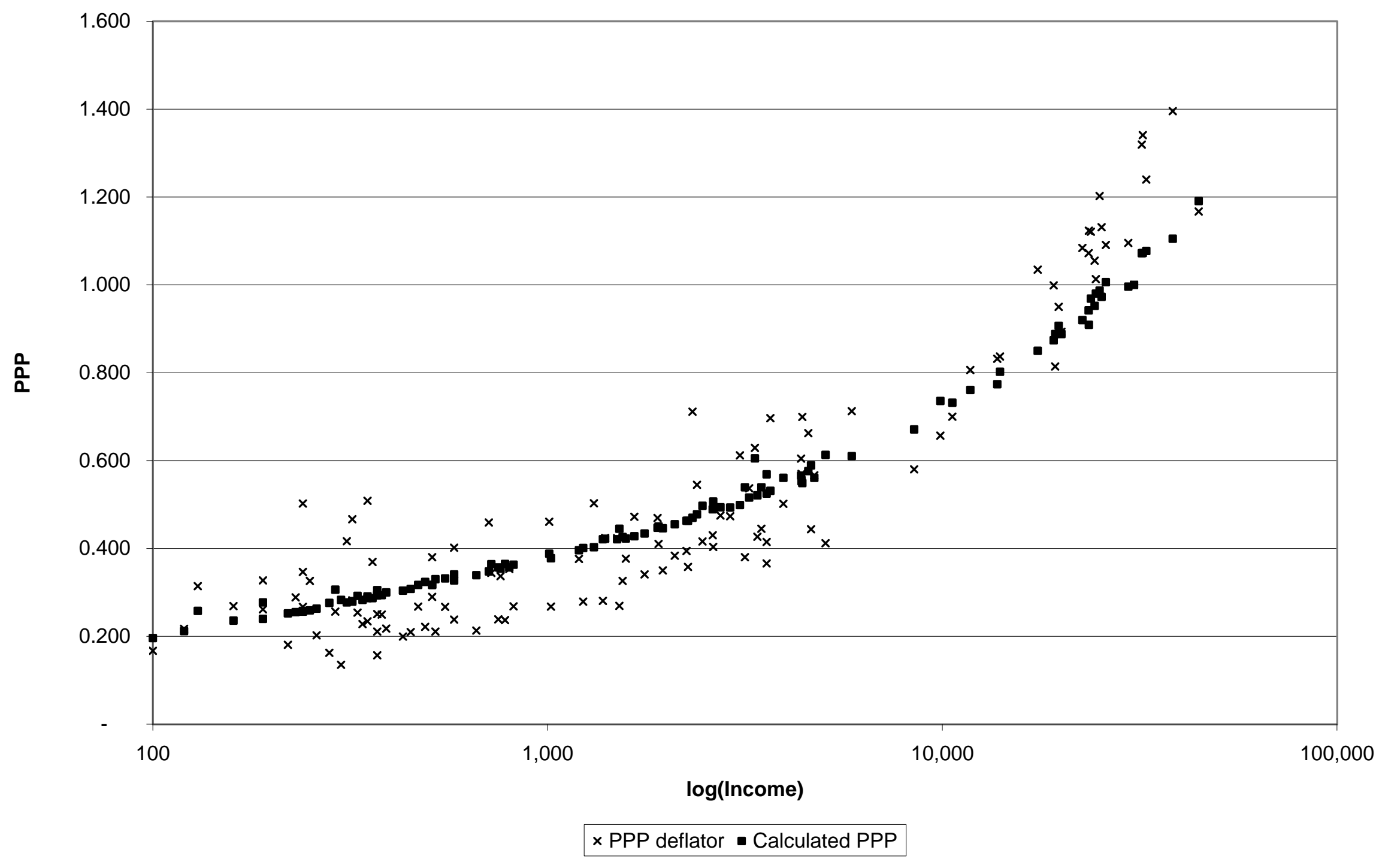

